\title{
Testing for Asymmetric Employer Learning
}

\author{
Uta Schönberg, University of Rochester
}

\begin{abstract}
Recent evidence suggests that employers acquire more precise information about a worker's productivity the more time he or she spends in the labor market. The following question arises: Is learning symmetric, that is, do all employers have the same information about workers' productivity, or is learning asymmetric, that is, does the current employer have superior information about workers' productivity? This article develops a learning model with endogenous mobility that nests both learning hypotheses. It then proposes new tests for asymmetric employer learning. Overall, learning appears to be mostly symmetric, except possibly when the employees involved are college graduates.
\end{abstract}

\section{Introduction}

In a world where the productivity of labor market participants is difficult to observe, a participant's individual career path and employment history forms a significant basis for any company's hiring decisions. The longer is a job candidate's employment history, the more information a recruiting firm can draw upon in assessing the candidate's ability to do the job for which he or she is being considered. Some information about the candidate's ability, such as his or her education or other contents of the curriculum vitae, is available to all recruiting firms. Other information may be available only to the candidate's current employer. As an illus-

I would like to thank Christian Dustmann, Kevin Lang, Alan Manning, and Costas Meghir for comments and suggestions. Financial support from the Economic and Social Research Council (ESRC) and the Gottlieb-Daimler und Karl-Benz Foundation is gratefully acknowledged. All errors are my own. Contact the author at utas@troi.cc.rochester.edu.

[Journal of Labor Economics, 2007, vol. 25, no. 4]

(C) 2007 by The University of Chicago. All rights reserved. 0734-306X/2007/2504-0005\$10.00 
tration, consider a lawyer. The incumbent firm is likely to use the number of cases the lawyer wins and loses to update its belief about his or her productivity. This information may also be available to outside firms. However, the incumbent firm may be better informed about the lawyer's ability to work as a member of a team or ability to cope with stress.

Do outside and current firms receive the same information about workers' productivity? This is termed "symmetric employer learning" in the literature. Models of this type were first analyzed by Freeman (1977) and Harris and Holmstrom (1982). Or do recruiting firms have an informational disadvantage relative to workers' current employers? This is termed "asymmetric employer learning" in the literature. Early examples of this type of model are Waldman (1984) and Greenwald (1986). The empirical evidence on whether learning is symmetric or asymmetric so far is inconclusive. While Farber and Gibbons (1996) and Altonji and Pierret (2001) provide evidence in favor of symmetric learning, Gibbons and Katz (1991) argue that employer learning is asymmetric.

This article attempts to distinguish between the two learning hypotheses. It sets up a learning model that nests both learning hypotheses, and it then proposes new tests for asymmetric employer learning. Distinguishing between symmetric and asymmetric learning is important for several reasons. First, the labor market may fail to efficiently allocate workers to jobs if learning is asymmetric. For instance, in the asymmetric learning models of Waldman (1984) and Bernhardt (1995), job assignment within firms is inefficient. ${ }^{1}$ Second, the type of employer learning affects the structure of wages. If learning is asymmetric, incumbent firms pay wages below productivity and general productivity is rewarded as if it were firm specific. This has important consequences for educational policies. As employers earn higher rents on more able workers, firms have an incentive to pay for general training if training and ability are complements (Waldman 1990; Acemoglu and Pischke 1998). Conversely, asymmetric learning distorts the incentive for workers to pay for skill acquisition. ${ }^{2}$ Third, the type of employer learning has consequences for statistical discrimination. Easily observable signals about workers' productivities, such as their education, will have a longer impact on wage determination under asymmetric learning than under symmetric learning.

${ }^{1}$ Golan (2005) sets up an asymmetric learning model in which job assignment is efficient. In contrast to Waldman (1984) and Bernhardt (1995), Golan assumes that workers' productivities in the high-level job and the low-level job are uncorrelated. In her model, productivity at the low-level job is publicly observed, while productivity at the high-level job is privately observed.

${ }^{2}$ In Golan (2005), asymmetric information does not lead to inefficient investment in training. This is because in this model assignment to jobs is efficient. 
There is thus more scope for statistical discrimination if learning is asymmetric. $^{3}$

My testing strategy proceeds in two steps. Both steps make use of a variable that is an indicator for workers' abilities but that is not observed by employers, such as a test score. A well-known consequence of asymmetric learning is that workers who switch firms are less able than workers who stay with their employer (e.g., Greenwald 1986; Gibbons and Katz 1991). I therefore begin by testing for an adverse selection of movers. Unlike the existing literature, I do this directly by estimating how ability measures affect the probability that a worker switches firms. My second test is a modification of Farber and Gibbons's (1996) and Altonji and Pierret's (2001) test for symmetric learning. I argue that hard- and easyto-observe variables, such as ability and education, have the same impact on wage offers of incumbent and outside firms if learning is symmetric. If, in contrast, incumbent firms are better informed about a worker's ability than are outside firms, then ability should have a stronger, and schooling a weaker, impact on wage offers of incumbent firms, as compared to those of outside firms. This is because incumbent firms use the newly acquired information about a worker's ability, while outside firms continue to use education as a signal when determining wages. I test these implications by analyzing how the impacts of the test score and schooling vary with tenure, controlling for interactions between these variables and experience.

The empirical analysis is based on the same data set that Farber and Gibbons (1996) and Altonji and Pierret (2001) use to test for symmetric learning, that of the National Longitudinal Survey of Youth 1979 (NLSY79). This data set contains the complete work history of a cohort of workers from their labor market entry onward. It focuses on young workers, for whom learning and firm mobility should matter the most. I follow Farber and Gibbons (1996) and Altonji and Pierret (2001) and use the Armed Forces Qualification Test (AFQT) as a variable that is correlated with ability but not observed by employers. The AFQT score provides a summary measure for basic literacy and numeric skills and is thus an indicator for workers' cognitive abilities. My tests are therefore best understood as tests for employer learning about workers' cognitive abilities, as opposed to employer learning about workers' noncognitive abilities, such as communication skills.

My results suggest that learning (about cognitive skills) is largely symmetric. There are, however, important differences across education groups.

${ }^{3}$ In a recent paper, Lange (2007) argues that employers learn quickly about workers' ability. As a consequence, signaling contributes little to the gains from schooling. However, Lange derives his results under the assumption that learning is purely symmetric. His conclusions may change if learning is asymmetric. 
For college graduates, the empirical evidence is potentially consistent with a model of asymmetric employer learning.

The plan of this article is as follows. Section II reviews existing tests for symmetric and asymmetric employer learning. Section III develops the learning model and contrasts the empirical implications of symmetric learning with those of asymmetric learning. Section IV describes the data, while Section V reports results. Section VI concludes and discusses alternative explanations for my findings.

\section{Existing Tests for Employer Learning}

This section briefly describes existing tests for symmetric and asymmetric learning. Gibbons and Katz (1991) were the first to provide a test for asymmetric learning. Others, such as Doiron (1995) and Grund (1999), have used their methodology to test for asymmetric learning in other countries.

Gibbons and Katz's test for asymmetric learning is based on the idea that, under asymmetric learning, the market will regard a layoff as a bad signal. No such stigma is attached to workers who are displaced from their firm for exogenous reasons, for instance, because of plant closure. This implies that laid-off workers are less able on average than exogenous movers, resulting in a lower postdisplacement wage for laid-off workers. Exogenous movers and laid-off workers look the same when they enter the labor market. Hence, asymmetric learning additionally predicts the same predisplacement wage for both groups of workers. Taken together, this implies a greater wage loss for laid-off workers than for exogenous movers. Using data from the Current Population Survey Displacement Survey, Gibbons and Katz (1991) find support for these hypotheses. ${ }^{4}$

This article directly tests the key implication of asymmetric learningthe adverse selection of movers-by analyzing the impact of ability measures on a worker's propensity to move away from his current employer. I attempt to further improve on Gibbons and Katz (1991) by proposing an additional test for asymmetric learning based on how easy- and hardto-observe variables affect wage offers of incumbent and outside firms.

In a recent paper, DeVaro and Waldman (2004) provide an alternative test for asymmetric employer learning that is not directly related to mine. Their starting point is that, under asymmetric employer learning, promotions act as a signal for workers' abilities. They derive two testable predictions. First, workers with high levels of education are promoted faster. Second, the wage increase associated with a promotion decreases with education. Using data on personnel records for managerial workers in a large firm, they find empirical support for both predictions.

${ }^{4}$ Krashinsky (2002) argues that accounting for establishment size removes much of the difference in the wage losses for the two groups of workers. 
Farber and Gibbons (1996) and Altonji and Pierret (2001) derive empirical implications of symmetric employer learning. Bauer and HaiskenDeNew (2001) and Galindo-Rueda (2003) use a similar methodology to test for employer learning in Germany and the United Kingdom, respectively. Lange (2007) extends Altonji and Pierret's (2001) framework to compute the signaling value of education. Farber and Gibbons (1996) derive their empirical predictions for wage levels, while Altonji and Pierret (2001) derive theirs for log wages. Both Farber and Gibbons (1996) and Altonji and Pierret (2001) assume that the effect of education (an easyto-observe variable) on a worker's productivity does not vary with labor market experience. Suppose that the econometrician has access to a variable that is correlated with ability but that is not observed by employers. Altonji and Pierret (2001) and Farber and Gibbons (1996) use (inter alia) the AFQT score as such a variable. They show that the coefficient on the AFQT score should increase with experience. ${ }^{5}$ This is because wages become increasingly dependent on ability as employers acquire new information about a worker's ability. Farber and Gibbons (1996) also show that the impact of education on wage levels should be independent of experience if the interaction between the AFQT score and experience is not included in the wage level regression. ${ }^{6}$ This is because, on average, future observations simply validate the relationship between expected productivity and schooling for labor market entrants. Finally, Altonji and Pierret (2001) argue that the effect of schooling should decline with experience if the interaction between the AFQT score and experience is included in the log-wage regression. ${ }^{7}$ This is because, at labor market entry, when only imprecise information about a worker's ability is available to firms, employers rely on easy-to-observe variables that are correlated with ability when determining wages. They do so less and less as they acquire more information about a worker's ability.

I argue that these implications are also consistent with asymmetric employer learning. I extend the learning model of Farber and Gibbons (1996) and Altonji and Pierret (2001) in two ways. ${ }^{8}$ First, my model allows

\footnotetext{
${ }^{5}$ To be precise, Farber and Gibbons (1996) show that the part of the AFQT score that is orthogonal to information available to employers at labor market entry increases with experience.

${ }^{6}$ This prediction depends on the functional form. If, as in Altonji and Pierret (2001), they had derived their predictions in logs, the same would hold in a logwage regression.

7 If the effect of education on productivity increases with experience (i.e., if education affects not only wage levels but also wage growth), then this prediction becomes weaker. In this case, the coefficient on the interaction between schooling and experience should be smaller if the interaction between the AFQT score and experience is included in the regression.

${ }^{8}$ However, my model is less general than the learning models of Farber and Gibbons (1996) and Altonji and Pierret (2001) as it considers two periods only.
} 
Table 1 Specification of Productivity

\begin{tabular}{lcc}
\hline & No College & College \\
\hline Low ability & $y_{L}^{u}=a_{L}$ & $y_{L}^{e}=a_{L}+s$ \\
High ability & $y_{H}^{u}=a_{H}$ & $y_{H}^{e}=a_{H}+s$ \\
Proportion low ability & $p^{N}$ & $p^{C}$ \\
\hline
\end{tabular}

for asymmetric learning and considers the symmetric learning model as a special case. Second, I introduce mobility into the model. ${ }^{9}$ These extensions allow me to modify the existing tests for symmetric employer learning such that it is possible to discriminate between the two learning hypotheses. The key insight is that ability and education affect wages of incumbent and outside firms in the same manner if learning is symmetric but differently if learning is asymmetric.

\section{Model}

This section sets up a simple learning model that nests the symmetric and the pure asymmetric learning model as special cases.

\section{A. Description of Environment}

There are many workers and firms, each of which is risk neutral. Firms maximize expected profits, and workers maximize expected utility. I consider two periods. There is no discounting.

\section{Productivity}

Workers differ with respect to ability and education. A worker's education is an easy to observe variable, one known to all employers. Ability may, in principle, comprise all of those characteristics that workers bring to the labor market that are hard to observe by employers, such as cognitive ability or communication skills. Workers are either of low $(L)$ or high $(H)$ ability, and they have attended either college $(C)$ or high school $(N)$. I denote education by the superscript $k, k=C, N$, and ability by the subscript $i, i=L, H$. Table 1 specifies the worker's productivity $y_{i}^{k}$.

This specification assumes that schooling increases the productivity of low-ability workers by as much as that of high-ability workers. I discuss the case in which schooling has a greater impact on the productivity of

${ }^{9}$ In many asymmetric learning models, such as those of Waldman $(1984,1996)$ and Bernhardt (1995), no worker switches firms. Other asymmetric learning models, such as Greenwald's (1986) and Gibbons and Katz's (1991), assume that some workers leave the firm for exogenous reasons. An example of an asymmetric learning model with endogenous mobility is that of Bernhardt and Scoones (1993). Also note that, in my model, mobility is voluntary. Laing (1994) develops an asymmetric learning model with involuntary layoffs. 
high-ability workers as compared to low-ability workers in Section III.D. There is no human capital accumulation.

Let $p^{N}$ and $p^{C}$ denote the proportion of low-ability workers among college graduates and high school graduates. The proportion of low-ability workers is higher among high school graduates than among college graduates, that is, $p^{N}>p^{C}$. Hence, education provides a useful signal for a worker's ability. There is ample empirical evidence of a positive correlation between education and ability. For instance, for Sweden, Meghir and Palme (2005) find that various measures of a child's cognitive ability subsequently increase his or her educational attainment. For the United States, Heckman and Vytlacil (2001), as well as Cawley, Heckman, and Vytlacil (2001), document a strong correlation between ability measures and schooling.

\section{Information Structure}

In the first period, firms and workers observe a worker's education but not his or her ability; information is symmetric between firms and workers. In the second period, incumbent firms get to know the worker's ability. In contrast, outside firms observe a common noisy signal about the worker's ability. It is important to stress that the signal is public, that is, all outside firms receive the same signal about a worker. The signal can take two values, good $(G)$ or bad $(B)$. I denote the signal by the superscript $s, s=G, B$. The signal is symmetric, that is, the probability that a low-ability worker generates a bad signal is the same as the probability that a high-ability worker generates a good signal. Moreover, the signal is independent of the worker's education. Let $q$ denote the probability that the firm observes the correct signal, $q \geq 0.5$. Outside firms use the signal, as well as education, to update their beliefs about the worker's productivity. They compute the probability that a worker is of low ability, conditional on education $k$ and on a good or bad signal, using Bayes's law:

$$
\begin{array}{ll}
p^{k, B}=\operatorname{Pr}(L \mid k, B)=\frac{p^{k} q}{p^{k} q+\left(1-p^{k}\right)(1-q)}, & k=C, N, \\
p^{k, G}=\operatorname{Pr}(L \mid k, G)=\frac{p^{k}(1-q)}{p^{k}(1-q)+\left(1-p^{k}\right) q}, & k=C, N .
\end{array}
$$

This specification nests the symmetric and pure asymmetric learning models as special cases. Suppose that $q=1$. In this case, all low-ability workers generate a bad signal and all high-ability workers generate a good signal. Hence, $\operatorname{Pr}(L \mid k, B)=1$, and $\operatorname{Pr}(L \mid k, G)=0$. Outside firms therefore have the same information about a worker's ability as incumbent firms, and learning is symmetric. Next, suppose that $q=0.5$. In this case, low-ability 
and high-ability workers generate a good or bad signal with equal probability. In other words, the signal contains no useful information that helps outside firms to predict a worker's ability. Hence, $\operatorname{Pr}(L \mid k, B)=$ $\operatorname{Pr}(L \mid k, G)=p^{k}$, and learning is purely asymmetric. In all intermediate cases $(0.5<q<1)$, outside firms receive new information about a worker's ability. Incumbent firms, however, are better informed about a worker's ability. I refer to the case $q=1$ as "symmetric learning" and to the case $q<1$ as "asymmetric learning."

\section{Mobility}

As in Acemoglu and Pischke (1998), workers experience a utility shock $\theta$ at the end of the first period. This shock captures a worker's ex-post evaluation of his or her work environment and may reflect distance to work, personal relationships with coworkers and superiors, health care programs, and so forth. Only the worker-not the firm-observes $\theta$. Alternatively, $\theta$ may be interpreted as a cost of moving. The utility shock is drawn from a distribution with the cumulative distribution function $G$ with associated probability distribution function $g$ and support $[\underline{\theta}, \bar{\theta}]$, $\bar{\theta}>0$. I assume that $G($.$) belongs to the family of log-concave distribution$ functions, that is, that $g(\theta) /(1-G(\theta))$ is nondecreasing in $\theta$. The distribution of the utility shock is independent of a worker's ability and his or her education.

I specify the worker's utility in period 2 at incumbent firms, $U$, as a linear function of the incumbent firm's wage offer, $w$, and the utility from nonpecuniary job characteristics, $\theta$ :

$$
U=w+\theta .
$$

The worker's utility at outside firms is equal to the outside firm's wage offer, $v$.

\section{Wage Determination}

Wages are determined in spot markets. This is in line with my assumption that workers are risk neutral. Consequently, workers do not benefit from long-term contracts that insure them against low realizations of their ability, as analyzed in Harris and Holmstrom (1982). In the first period, firms simultaneously make wage offers to workers. In the second period, outside firms simultaneously make wage offers to workers. An incumbent firm observes a worker's (best) outside wage offer and then makes a counteroffer. This wage determination process has been adopted in most of the literature on asymmetric employer learning (e.g., Waldman 
1984; Greenwald 1986; Gibbons and Katz 1991). ${ }^{10}$ Finally, I impose a free entry condition: no firm earns positive (expected) profits in the long run.

\section{Free Entry}

To summarize, the timing of events is as follows. At the beginning of period 1, firms simultaneously make wage offers to workers. Firms observe a worker's education but not his or her ability. Information is symmetric between firms and workers. Each worker chooses the highest wage offer. Then production takes place. Incumbent firms observe the worker's ability, while outside firms receive a common noisy signal. At the beginning of period 2, outside firms simultaneously make wage offers to workers. Incumbent firms observe a worker's (best) outside offer and make a counteroffer. Workers then discover their utility shocks and decide whether or not to stay with their initial employers. At the end of the second period, workers retire.

Section III.B analyzes the model. Section III.C contrasts the empirical implications of symmetric learning with those of asymmetric learning, and Section III.D. presents some alternative assumptions. Section III.E describes how I take these implications to the data.

\section{B. Analysis}

\section{Wage Determination in the Second Period}

I begin with wage determination in the second period. In the second period, outside firms do not directly observe a worker's ability but obtain only a noisy signal. They use the signal in conjunction with a worker's education to update their belief about the worker's ability. Consequently, wage offers of outside firms depend on education as well as the signal. I therefore index wage offers of outside firms by the superscripts $k$ (education) and $s$ (signal). Incumbent firms, in contrast, directly observe a worker's ability. Since incumbent firms observe the wage offers from outside firms and outside firms offer a higher wage if a good signal is observed, wage offers of incumbent firms depend not only on education and ability but also on signals. I therefore index wage offers of incumbent firms by the subscript $i$ (ability) and the superscripts $k$ (education) and $s$ (signal).

Incumbent firms. - First, consider incumbent firms. Incumbent firms face the trade-off between a higher chance of keeping a worker and a lower profit per worker. Suppose that the best wage offer a worker with education $k$ and ability $i$ has received from an outside firm is $v^{k, s}$. The worker stays

${ }^{10}$ Golan (2002) develops a model of asymmetric employer learning with an alternative wage determination process. She departs from the assumption that workers are price-takers and allows firms and workers to bargain over wages. 
with his or her employer if the wage offer of the incumbent firm, $w_{i}^{k, s}$, plus the utility shock, $\theta$, exceeds his or her best outside wage offer:

$$
\begin{aligned}
\operatorname{Pr}(\text { stay } \mid i, k, s)= & \operatorname{Pr}\left(w_{i}^{k, s}+\theta>v^{k, s}\right) \\
= & 1-G\left(v^{k, s}-w^{k, s}\right), \\
& i=L, H ; k=C, N ; s=B, G .
\end{aligned}
$$

Incumbent firms maximize as follows:

$$
\begin{gathered}
\max _{w_{i}^{k},}\left[1-G\left(v^{k, s}-w_{i}^{k, s}\right)\right]\left(y_{i}^{k}-w_{i}^{k, s}\right), \\
i=L, H ; k=C, N ; s=B, G .
\end{gathered}
$$

The first-order condition may be written as

$$
w_{i}^{k, s}=y_{i}^{k}-\frac{1-G\left(v^{k, s}-w_{i}^{k, s}\right)}{g\left(v^{k, s}-w_{i}^{k, s}\right)} .
$$

Outside firms. - Next, consider outside firms. Due to perfect competition in the outside market, outside wages are bid up to the expected productivity of those workers who switch firms. Since, conditional on the signal, low-ability workers receive the same wage offer as high-ability workers but a lower wage offer from incumbent firms, they are more likely to switch firms than are high-ability workers. Outside firms must account for this adverse selection of movers when deciding which wage to offer. Let $p^{k, s}$ denote the probability that a worker with education $k$ and signal $s$ is of low ability. (See eqq. [1] and [2] in Sec. III.A for how $p^{k, s}$ is computed.) Outside wages equal

$$
\begin{aligned}
v^{k, s} & =\frac{\operatorname{Pr}(L \mid \text { move, } s) y_{L}^{k}+\operatorname{Pr}(H \mid \text { move, } s) y_{H}^{k}}{\operatorname{Pr}(L \mid \text { move, } s)+\operatorname{Pr}(H \mid \text { move, } s)} \\
& =\frac{p^{k, s} G\left(v^{k, s}-w_{L}^{k, s}\right) y_{L}^{k}+\left(1-p^{k, s}\right) G\left(v^{k, s}-w_{H}^{k, s}\right) y_{H}^{k}}{p^{k, s} G\left(v^{k, s}-w_{L}^{k, s}\right)+\left(1-p^{k, s}\right) G\left(v^{k, s}-w_{H}^{k, s}\right)} .
\end{aligned}
$$

In Appendix A, Section 1, I show that an equilibrium exists, that it is unique, and that first-order conditions are sufficient for a maximum.

\section{Wage Determination in the First Period}

I analyze wage determination in the first period in more detail in Appendix A, Section 2. At this point, it is important to bear in mind that, in the first period, firms observe a worker's education but not his or her ability. Since education is the only signal that firms have about a worker's productivity, wages in the first period depend on education but not on ability. 


\section{Symmetric versus Asymmetric Learning}

This section contrasts the empirical implications of the symmetric learning model (i.e., $q=1$ ) with those of the asymmetric learning model (i.e., $q<1$ ). I first analyze how ability affects the probability of staying and moving under each learning hypothesis (Sec. III.C.1). I then modify Farber and Gibbons's (1996) and Altonji and Pierret's (2001) implications of symmetric learning in order to distinguish between the two learning hypotheses (Sec. III.C.2). All formal proofs can be found in Appendix A, Sections 3-5.

\section{Ability and the Probability of Switching Firms}

First consider the case in which incumbent and outside firms have the same information about a worker's productivity (i.e., $q=1$ ). In this case, a worker is of low ability if a bad signal is observed and is of high ability if a good signal is observed (i.e., $p^{k, B}=1$ and $p^{k, G}=0$ ). Hence, outside firms offer wages equal to $y_{L}^{k}\left(y_{H}^{k}\right)$ if they observe a bad (good) signal. It is easy to verify that, in this case, an incumbent wage offer is equal to the worker's productivity minus a positive constant $\Delta$,

$$
w_{i}^{k}=y_{i}^{k}-\Delta \text {. }
$$

Consequently, $v_{L}^{k}-w_{L}^{k}=v_{H}^{k}-w_{H}^{k}$, and therefore $\operatorname{Pr}(\operatorname{move} \mid L, k)=$ $\operatorname{Pr}$ (move $\mid H, k$ ), and low- and high-ability workers have the same probability of leaving the firm (see App. A, Sec. 3, for details).

Contrast this with the case in which there are informational asymmetries between incumbent and outside firms (i.e., $q<1$ ). Conditional on a good or a bad signal, high-ability workers receive the same wage offer as low-ability workers from outside firms, but they receive a higher wage offer from incumbent firms. Hence, conditional on the signal, low-ability workers are more likely to leave the firm than are high-ability workers. ${ }^{11}$ In Appendix A, Section 3, I show that this also holds unconditionally, integrating over the signal realization.

\section{The Impact of Ability and Schooling on Wage Offers of Incumbent and Outside Firms}

Next, I argue that Farber and Gibbons's (1996) and Altonji and Pierret's (2001) implications of symmetric learning are also consistent with asymmetric employer learning. I show how the implications can be modified such that it is possible to distinguish symmetric from asymmetric learning. I begin with the impact of ability on wage offers of incumbent and outside firms. I then turn to the impact of education on wage offers.

${ }^{11}$ Of course, this result is well known in the literature (e.g., Greenwald 1986; Gibbons and Katz 1991). 
The effect of ability on incumbent and outside wage offers. - Suppose that learning is symmetric, that is, that $q=1$. Under this assumption, Farber and Gibbons (1996) and Altonji and Pierret (2001) show that wages become increasingly sensitive to ability. Clearly, this is also the case in this model: wage offers in the first period do not vary with ability since firms do not observe it. In the second period, firms learn about a worker's ability and offer different wages to low-ability and high-ability workers. Thus, the impact of ability on wages is stronger in the second period than in the first. Note that this reasoning also holds even if learning is purely asymmetric because wage offers of incumbent firms depend on ability.

My key insight is that the two learning hypotheses differ with respect to how ability affects the wage offers of incumbent and outside firms. First, consider the case in which incumbent and outside firms have the same information about a worker's ability $(q=1)$. As shown earlier, this implies that outside firms offer wages equal to a worker's productivity while incumbent firms offer wages equal to a worker's productivity minus a constant. Consequently, $w_{H}^{k}-w_{L}^{k}=v_{H}^{k}-v_{L}^{k}$, and ability has the same effect on wage offers of incumbent firms as on those of outside firms.

Contrast this with the case in which incumbent firms are better informed about workers' abilities $(q<1)$. Here, as shown earlier, conditional on the signal, wage offers of incumbent firms vary with ability, while wage offers of incumbent firms do not. In Appendix A, Section 4, I show that unconditionally (integrating over the signal realization) wage offers of incumbent firms continue to vary more with ability than wage offers of outside firms.

The effect of education on the wage offers of incumbent and outside firms. - Next, I analyze how education affects the wage offers of incumbent and outside firms. Suppose that learning is symmetric $(q=1)$. In this case (and under the assumption that the impact of education on productivity is independent of experience), Altonji and Pierret (2001) show that the impact of education declines with experience if interactions between ability measures and experience are included in the wage regression. The reason is that firms rely less and less on easily observable signals like education when determining wages as they learn more about workers' abilities. The same intuition holds in my model. However, a declining effect of education with experience is also consistent with asymmetric learning.

Again, the two learning hypotheses differ with respect to how schooling affects wage offers of incumbent and outside firms. First, consider the case of symmetric learning. Recall that in this case, wage offers of outside firms are equal to workers' productivity, while wage offers of incumbent firms are equal to workers' productivity minus a constant. Consequently, conditional on ability, the difference between wage offers of incumbent and outside firms to college graduates and high school graduates is $y_{i}^{C}-$ 
$y_{i}^{N}=s$ and schooling has the same impact on wage offers of incumbent and outside firms.

Next, suppose that incumbent firms observe a worker's ability but that outside firms are only imperfectly informed about workers' ability $(q<$ 1). In this case, outside firms continue to use a worker's education as a signal of ability. Wage offers of outside firms to college graduates therefore reflect not only the productivity-enhancing effect of education, $s$, but also the fact that college graduates are more able on average than high school graduates. Hence, schooling has a stronger impact on wage offers of outside firms than on those of incumbent firms. See Appendix A, Section 5, for a formal proof.

To sum up, under symmetric learning, low-ability and high-ability workers are equally likely to switch firms and the impact of ability and education on wage offers of incumbent firms is the same as on those of outside firms. If, in contrast, there are informational asymmetries between incumbent and outside firms, then low-ability workers are more likely to leave the firm than are high-ability workers and wage offers of incumbent firms are more sensitive to ability and less sensitive to education than wage offers of outside firms.

The next section first analyzes how these predictions change when ability and education are complements. I then briefly discuss the case in which firms receive private signals and incumbent firms learn only imperfectly about a worker's ability.

\section{Alternative Assumptions}

\section{Complementarity between Ability and Education}

So far I have assumed that schooling raises the productivity of lowability workers the same as that of high-ability workers. This section discusses the case in which schooling raises the productivity of high-ability workers more than that of low-ability workers. All formal proofs can be found in Appendix A, Section 6.

Most important, such a complementarity between schooling and ability produces two additional implications if learning is asymmetric. First, the adverse selection of firm-switchers should be greater for college graduates than for high school graduates as schooling magnifies the impact of ability differences on output. For the same reason, the difference between the impact of ability on wage offers of incumbent and outside firms should be larger for college graduates than for high school graduates.

In addition, the complementarity between ability and education weakens the prediction that, under asymmetric learning, wage offers of outside firms vary more with education than wage offers of incumbent firms. This prediction still holds for low-ability workers. However, it may no longer hold for high-ability workers. This is because, for high-ability 
workers, there are two effects that work in opposite directions. On the one hand, wage offers of outside firms vary more with education than wage offers of incumbent firms because outside firms continue to use education as a signal while incumbent firms do not. On the other hand, education increases wage offers made by incumbent firms to high-ability workers more than it increases wage offers made by outside firms to such workers because, in contrast to outside firms, incumbent firms know for sure whether a worker is of high ability.

\section{Private Signals and Imperfect Learning}

So far I have assumed that outside firms receive public signals and that incumbent firms get to know fully a worker's ability. This section discusses the case in which signals are private and incumbent firms imperfectly learn about a worker's ability. ${ }^{12}$ For simplicity, suppose that, in each period, there are only two firms competing for workers. Further suppose that, in each period, both firms receive a private signal about a worker's ability and that this information is symmetric in the sense that the precision of the signal is the same for both the incumbent firm and the outside firm. It is still the case that the incumbent firm will be better informed about a worker's ability than will be the outside firm. This is because the incumbent firm observes the worker's outside offer, which conveys information on the signal of the outside firm. This model leads to the same empirical implications as my asymmetric learning model. I view this model as being an alternative model of asymmetric information, one in which informational asymmetry is due not to the incumbent firm receiving more precise signals but instead to the counteroffer structure of the wage determination process. My tests of symmetric learning are therefore best understood as tests for whether or not incumbent firms are better informed in equilibrium than outside firms and not for whether incumbent firms receive more precise signals than outside firms.

\section{E. Empirical Implementation}

This section describes how I take the predictions of symmetric and asymmetric employer learning to the data. My tests make use of a variable that is correlated with ability but that is not observed by employers. Following Farber and Gibbons (1996) and Altonji and Pierret (2001), I use the AFQT for this purpose. ${ }^{13}$

${ }^{12}$ Pinkston (2005) develops a learning model with private signals and derives testable implications.

${ }^{13}$ The assumption that econometricians have information on workers that is not available to firms is unusual. I would like to point out that this assumption does not rule out that firms have some information about workers' productivities that is not observed by the econometrician. What is required is that firms do not observe (or do not use) the AFQT to make inferences about workers' productivities. 
A key implication of asymmetric employer learning is that low-ability workers are more likely to leave the firm than are high-ability workers. I test this implication directly by estimating the effect of the AFQT score on the worker's probability of leaving the firm, using a probit model. ${ }^{14}$ If ability and education are complements, asymmetric learning further implies a stronger adverse selection for better-educated workers. In some specifications, I therefore allow the impact of the AFQT score to vary with education.

My second set of tests refers to how ability and education affect the wage offers of incumbent and outside firms. To test these predictions, I extend the main wage regression estimated by Altonji and Pierret (2001) as follows:

$$
\begin{aligned}
\ln w_{i t}= & \beta_{0}+\beta_{1} E_{i t}+\beta_{2} T_{i t}+\beta_{3} \mathrm{AFQT}_{i} \\
& +\left(\beta_{4} E_{i t} \times \mathrm{AFQT}_{i}\right)+\left(\beta_{5} T_{i t} \times \mathrm{AFQT}_{i}\right)+\beta_{6} S_{i} \\
& +\left(\beta_{7} E_{i t} \times S_{i}\right)+\left(\beta_{8} T_{i t} \times S_{i}\right)+\beta_{9} X_{i t}+u_{i t},
\end{aligned}
$$

where $E_{i t}$ denotes (actual) experience, $T_{i t}$ denotes tenure, $S_{i}$ denotes schooling, and $X_{i t}$ is a vector of (possibly time-varying) worker characteristics. The main coefficients of interest are $\beta_{5}$, the coefficient on the interaction between tenure and the AFQT score, and $\beta_{8}$, the coefficient on the interaction between tenure and schooling. Suppose that the data are generated exactly as my stylized two-period model predicts. Then $\beta_{5}$ and $\beta_{8}$ identify the difference between the impact of ability and schooling on wage offers of incumbent and outside firms, conditional on accepting the incumbent or outside firm's wage offer. If learning is symmetric $(q=1)$, then ability and education have the same impact on wage offers of incumbent and outside firms. Hence, $\beta_{5}$ and $\beta_{8}$ should be equal to zero. If, in contrast, learning is asymmetric $(q<1)$, then wage offers of incumbent firms vary more with ability and less with education than wage offers of outside firms. However, accepted wages may differ from offered wages because the type of signal a worker receives may affect the probability that he stays with the firm. ${ }^{15}$ Unfortunately, I was not able to show an-

${ }^{14}$ A probit model is suggested by my model if nonpecuniary job charactersitics are drawn from a normal distribution.

${ }^{15}$ For example, low-ability workers are, on average, offered a wage $q w_{L}^{k, B}+$ $(1-q) w_{L}^{k, G}$ from incumbent firms and $q v^{k, B}+(1-q) v^{k, G}$ from outside firms. Accepted wages from incumbent and outside firms, in contrast, equal

$$
\begin{gathered}
\frac{q\left[1-G\left(v^{k, B}-w_{L}^{k, B}\right)\right] w_{L}^{k, B}+(1-q)\left[1-G\left(v^{k, G}-w_{L}^{k, G}\right)\right] w_{L}^{k, G}}{q\left[1-G\left(v^{k, B}-w_{L}^{k, B}\right)\right]+(1-q)\left[1-G\left(v^{k, G}-w_{L}^{k, G}\right)\right]}, \\
\frac{q G\left(v^{k, B}-w_{L}^{k, B}\right) v^{k, B}+(1-q) G\left(v^{k, G}-w_{L}^{k, G}\right) v^{k, G}}{q G\left(v^{k, B}-w_{L}^{k, B}\right)+(1-q) G\left(v^{k, G}-w_{L}^{k, G}\right)} .
\end{gathered}
$$


alytically that accepted wages of incumbent firms are more sensitive to ability and less sensitive to education than are accepted wages of outside firms. I have computed equilibrium wages under the assumption that nonpecuniary job characteristics are drawn from a logistic or a normal distribution. I could not find any parameter values for which wage offers of incumbent firms did not vary more with ability and less with education than wage offers of outside firms, conditional on acceptance. This suggests that the implications hold not only for offered wages but also for accepted wages.

To summarize, I test two one-sided hypotheses: first, $\beta_{5}=0$ against $\beta_{5}>0$, and second, $\beta_{8}=0$ against $\beta_{8}<0$. The null hypothesis implies that learning is symmetric, while the alternative hypothesis implies that learning is asymmetric. Note that the alternative hypothesis merely implies that incumbent firms have superior information about a worker's ability; it does not imply that outside firms receive no new information. ${ }^{16}$

An implicit assumption behind regression (5) is that schooling increases the productivity of low-ability workers as much as that of high-ability workers. In a final step of the empirical analysis, I augment regression (5) to allow for a possible complementarity between education and ability.

Of course, labor market careers last more than two periods. By estimating regression (5) on multiperiod data, I am essentially stepping outside of my model. Unfortunately, extending the set-up to multiperiods is very difficult. For instance, workers may choose to stay with the employer even if the outside offer provides a higher current utility in order to signal that they are of high ability. Firms have to take into account such strategic behavior of workers when deciding which wages to offer. While a more dynamic version would clearly be desirable, it is beyond the scope of this article.

\section{Data Description and Variables}

The data come from the NLSY79 and encompass the years 1979-2001. This data set is well suited to my purpose. First, it contains the complete work history, including all job-to-job and job-to-unemployment transitions, of a cohort of workers from their labor market entry onward. It thus focuses on young workers for whom learning and worker mobility should matter the most. Second, for each respondent, it contains a test score variable that is unlikely to be observed by employers, which is crucial for testing for asymmetric employer learning.

Because I do not want to deal with a woman's fertility decision, I focus on men only. Moreover, I restrict the analysis to white men, doing so for

\footnotetext{
${ }^{16}$ Note that $\beta_{4}$ should be equal to zero if outside firms receive no new information about workers' ability. Hence, the null hypothesis of $\beta_{4}=0$ tests whether employer learning is purely asymmetric.
} 
two reasons: first, models of statistical discrimination-in particular, models in which employers are better informed about whites than about blacks-imply that the learning process is different for blacks and whites; second, Hu and Taber (2005) repeat the empirical analysis of Gibbons and Katz (1991) and provide evidence in favor of asymmetric employer learning only for white men and not for black men. ${ }^{17}$ Estimating the same model for blacks and whites may thus be misleading.

For each respondent, I construct the labor market history from the NLSY79 Work-History file, which contains week-by-week longitudinal work records. From this file, I select the respondent's labor force status and job number at the beginning of each quarter (i.e., I select the first week in 1978, the fourteenth week in 1978, . . the first week in 1979, the fourteenth week in 1979, etc.). For multiple job holders, I define the main job as the job at which the worker worked the most during the week. I consider only the main job for each respondent and ignore additional jobs. I match to this data set the educational histories of each respondent, that is, his enrollment status as well as his highest grade completed.

A major problem in the NLSY79 concerns the type of employment relations one should consider in the analysis. I consider only jobs held after the respondent has entered the labor market. Labor market entry is difficult to define because working while enrolled at school is very common. See Appendix B, Section 3 for the precise definition.

My sample is then created as follows. There are 2,439 white men in the cross-sectional sample of the NLSY79. Out of those, 95 have never made a transition from school to work according to my definition. I drop individuals who entered the labor market before 1978, since detailed information about weeks worked and employers worked for is only available starting January 1978. I lose 659 individuals because of this. This leaves me with 1,685 individuals.

As did Farber and Gibbons (1996) and Altonji and Pierret (2001), I use the AFQT as a variable that is correlated with ability but that is not observed by employers. The AFQT provides a summary measure of basic literacy and numeric skills. It is generally seen as a good indicator of workers' cognitive abilities but as probably not as good an indicator of workers' communication skills. My tests are therefore best understood as tests for the employer learning about workers' cognitive abilities. In my sample, the AFQT score is missing for 76 individuals. For a further 20 individuals, the test conditions were altered. I drop these individuals. This leaves me with 1,589 individuals. Since respondents were of different ages when they took the AFQT, I adjust the test score for the respondent's

${ }^{17} \mathrm{Hu}$ and Taber (2005) do not find evidence for a lemons effect for white and black women. 
age at the test. Following the literature, I standardize the AFQT score to have a zero mean and a standard deviation of one.

My first test for symmetric versus asymmetric learning is based on how ability affects the probability of leaving the firm. I test this using quarterly data, where the dependent variable is equal to one if the worker leaves the firm during the quarter and zero otherwise. Note that the quarterly quit rate is not defined for workers who were not employed at the beginning of the quarter. I require a mover to have left his job permanently. Workers who have been laid off and who return to their previous firm are considered as stayers. I do this because the employing firm has essentially the same information about these workers' productivities as do other incumbent firms, and this information is potentially superior to the information of other outside firms. I drop observations if the worker did not work for pay, was employed in the agricultural sector, or was employed part time ( $<30$ hours) at the beginning of the quarter. Finally, I drop spells with missing information on highest grade completed or industry and occupation affiliation. I lose one individual because of these restrictions. My final sample consists of 1,588 individuals and 87,121 quarterly observations.

My second test for symmetric versus asymmetric learning is based on how the impact of the AFQT score and education changes with tenure. In order to test these implications, I transform the quarterly data set into a spell data set, and I keep one observation per job and interview year. I do this because wage data are not available for each quarter. I drop observations with hourly wage rates smaller than $\$ 1$ or greater than $\$ 500$. My final sample consists of 1,584 individuals and 22,093 observations. Details on how the spell data set was constructed can be found in Appendix B, Section 2.

After experimenting with several definitions, I decided to distinguish between two education groups. I label these two groups "high school graduates" and "college graduates." High school graduates are workers without bachelor's degree. They include high school dropouts as well as workers with some college education. College graduates are workers who completed (at least) a bachelor's degree. Results for high school dropouts and high school graduates with and without some college education are similar, so I decided not to distinguish between these three groups. Table 2 reports the means and standard deviations for both the quarterly and the spell data of the most important variables used for the analysis.

\section{Empirical Evidence}

My testing strategy proceeds in two steps. First, I analyze how the AFQT score affects the probability of switching firms (Sec. V.A). Second, I test whether easy- and hard-to-observe variables have the same or dif- 
Testing for Asymmetric Employer Learning

Table 2

Means and Standard Deviations of Selected Variables

\begin{tabular}{lcc}
\hline & $\begin{array}{c}\text { High School } \\
\text { Graduates }\end{array}$ & $\begin{array}{c}\text { College } \\
\text { Graduates }\end{array}$ \\
\hline Quarterly data: & & \\
No. individuals & 1,032 & 556 \\
No. observations & 57,637 & 29,452 \\
Adjusted AFQT score & -.097 & 1.103 \\
& $(.874)$ & $(.610)$ \\
Proportion moving (\%) & 9.15 & 6.24 \\
Actual experience & 7.364 & 6.840 \\
& $(4.997)$ & $(4.643)$ \\
Tenure & 3.504 & 3.743 \\
& $(3.817)$ & $(3.698)$ \\
No. jobs & 5.579 & 4.230 \\
& $(3.820)$ & $(2.965)$ \\
Spell data: & 1,032 & \\
No. individuals & 15,205 & 552 \\
No. observations & -.120 & 6,888 \\
Adjusted AFQT score & $(.871)$ & 1.097 \\
& 7.547 & $(.609)$ \\
Experience & $(5.004)$ & $(4.296$ \\
& 2.957 & $3.749)$ \\
Tenure & $(3.359)$ & $(3.366)$ \\
& 4.806 & 3.592 \\
No. jobs & $(3.789)$ & $(2.737)$ \\
Real hourly wage rate (in cents) & 744.13 & $1,170.80$ \\
& $(619.65)$ & $(982.87)$ \\
\hline Note.-Quarterly data are used to test how the AFQT score affect the probability of \\
switching firms. Spell data are used to test how the AFQT score affects wage offers of \\
incumbent and outside firms. Standard deviations are in parentheses. See App. B for details \\
on the sample creation and variable definitions. & & \\
& &
\end{tabular}

ferent impacts on wage offers of incumbent and outside firms (Sec. V.B). I discuss potential alternative explanations for my findings in Section VI.

\section{A. Are Movers Negatively Selected?}

If there are informational asymmetries between incumbent and outside firms, then low-ability workers are more likely to leave the firm than are high-ability workers. Symmetric learning, in contrast, predicts no such adverse selection. I test this prediction by estimating probit models with the quarterly quit rate as the dependent variable. The key (one-sided) hypothesis test is whether the coefficient on the AFQT score is zero (symmetric learning) or negative (asymmetric learning).

Panel A of table 3 presents the results. Row A restricts the impact of the AFQT score to be the same for college graduates and high school graduates, while row $\mathrm{B}$ allows the effect to be different. In addition to the variables reported in the table, column 1 controls for years of schooling, year effects, experience, tenure, and whether the interview took place 
Table 3

The Impact of the AFQT Score on the Probability of Moving

\begin{tabular}{|c|c|c|}
\hline & \multicolumn{2}{|c|}{$\begin{array}{c}\text { Panel A: } \\
\text { Probability of Moving }\end{array}$} \\
\hline & 1 & 2 \\
\hline A. AFQT & $\begin{array}{l}-.004 * * \\
(.002)\end{array}$ & $\begin{array}{c}-.002 \\
(.001)\end{array}$ \\
\hline $\begin{array}{l}\text { 1. } H_{0} \text { : industrial and occupation } \\
\text { dummies }=0\end{array}$ & & .000 \\
\hline B. AFQT & $\begin{array}{c}-.003 \\
(.002)\end{array}$ & $\begin{array}{c}-.001 \\
(.002)\end{array}$ \\
\hline AFQT $\times$ college & & \\
\hline \multirow[t]{2}{*}{$\begin{array}{l}\text { 2. } H_{0} \beta_{\mathrm{AFQT}}+\beta_{\mathrm{AFQT} \times \text { college }}=0 \\
\text { 3. } H_{0}: \text { industry and occupation } \\
\text { dummies }=0\end{array}$} & .005 & $\begin{array}{l}.028 \\
.000\end{array}$ \\
\hline & \multicolumn{2}{|c|}{$\begin{array}{c}\text { Panel B: } \\
\text { Job-to-Job versus } \\
\text { Job-to-Unemployment } \\
\text { Transitions }\end{array}$} \\
\hline A. AFQT, jtj & $\begin{array}{c}-.018 \\
(.025)\end{array}$ & $\begin{array}{l}.009 \\
(.025)\end{array}$ \\
\hline AFQT, jtu & $\begin{array}{l}-.136 * * \\
(.036)\end{array}$ & $\begin{array}{l}-.095 \% * \\
(.036)\end{array}$ \\
\hline $\begin{array}{l}\text { 1. } H_{0} \text { : industry and occupation } \\
\text { dummies }=0\end{array}$ & & .000 \\
\hline $\mathrm{B}: \mathrm{AFQT}, \mathrm{jtj}$ & $\begin{array}{l}.010 \\
(.029)\end{array}$ & $\begin{array}{l}.037 \\
(.029)\end{array}$ \\
\hline AFQT, jtu & $\begin{array}{l}-.141 * * \\
(.040)\end{array}$ & $\begin{array}{l}-.102 * \\
(.040)\end{array}$ \\
\hline AFQT $\times$ college, $j \mathrm{j} j$ & $\begin{array}{l}-.136 \% * \\
(.050)\end{array}$ & $\begin{array}{l}-.139 \% * \\
(.051)\end{array}$ \\
\hline AFQT $\times$ college, jtu & $\begin{array}{l}.037 \\
(.087)\end{array}$ & $\begin{array}{l}.053 \\
(.088)\end{array}$ \\
\hline $\begin{array}{l}\text { 2. } H_{0}: \beta_{\mathrm{AFQT}}+\beta_{\mathrm{AFQT} \times \text { college }}=0, \mathrm{jtj} \\
\text { 3. } H_{0}: \beta_{\mathrm{AFQT}}+\beta_{\mathrm{AFQT}} \times \text { college }=0, \mathrm{jtu} \\
\text { 4. } H_{0}: \beta_{\mathrm{AFQT} \times \text { college }}=0, \mathrm{jtj}+\mathrm{jtu} \\
\text { 5. } H_{0}: \text { industry and occupation }\end{array}$ & $\begin{array}{l}.003 \\
.187 \\
.013\end{array}$ & $\begin{array}{l}.019 \\
.528 \\
.013\end{array}$ \\
\hline dummies $=0$ & & .000 \\
\hline
\end{tabular}

Note. $-N=87,086$. The dependent variable in panel $\mathrm{A}$ is equal to one if the worker switches firms in a quarter, and zero otherwise. Probit models, marginal effects, are reported. The dependent variable in panel B is equal to zero if the worker stays, one if he moves from job-to-job (jtj), and two if he moves from job-to-unemployment (jtu). Multinominal logit models, stayers, are the base category. White/Huber standard errors clustered at the individual level are in parentheses. In addition to the variables reported, col. 1 controls for college graduation, year dummies, experience, tenure, highest grade completed, and a dummy variable if the interview took place during the quarter, while col. 2 additionally includes 12 industry and seven occupation dummies. Row A restricts the effect of the AFQT score to be the same for high school graduates and college graduates. Row B allows the effect of the AFQT score to vary by college graduation. The $p$-values refer to a two-sided hypothesis test.

$* p<.05$.

$* * p<.01$. 
during the quarter; ${ }^{18}$ column 2 additionally includes industry and occupation dummies. I control for industry and occupation affiliation for the following reason. Suppose that some industries and occupations offer more stable jobs than others and that more able workers sort into more stable industries and occupations. ${ }^{19}$ Unconditional on industry and occupation, such a sorting model provides an alternative explanation for a negative correlation between ability and mobility.

First, consider the results in row A, column 1 of table 3. According to this specification, an increase in the AFQT score by one standard deviation reduces the quarterly moving rate by 0.38 percentage points. The overall quarterly quit rate is $8.16 \%$; hence, an increase in the AFQT score by one standard deviation lowers the quarterly quit rate by about $4.6 \%$. The effect is statistically significant. For this specification, I therefore reject the null hypothesis of symmetric learning in favor of the alternative hypothesis of asymmetric learning. If, however, I also control for industry and occupation affiliation (col. 2), the coefficient on the AFQT score becomes smaller in magnitude and is no longer statistically significant. This indicates that sorting by ability into occupations and industries is important, and it casts some doubt on the hypothesis that the adverse selection of movers in row $\mathrm{A}$ is due to asymmetric information.

Results in row A of panel A of table 3 restrict the effect of the AFQT score to be the same for high school graduates and college graduates. However, my model predicts a stronger adverse selection for college graduates if learning is asymmetric and education and ability are complements. Row B of table 3 therefore allows the effect of the AFQT score to be different for college graduates and high school graduates. The adverse selection is indeed stronger for college graduates. According to specification 2, an increase in the AFQT score by one standard deviation lowers the quarterly quit rate for high school graduates by 0.1 percentage points, or about $1 \%$ of the baseline. ${ }^{20}$ For college graduates, in contrast, the decrease is $0.5((0.001+0.004) \times 100)$ percentage points, or $8 \%$ of the baseline. ${ }^{21}$ For this specification, I therefore reject the hypothesis of sym-

\footnotetext{
${ }^{18}$ The coefficient on the variable denoting whether the interview took place during the quarter is highly statistically significant. The sign indicates that workers are more likely to report recent firm switches than firm switches that took place some time ago. This may cast some doubt on the quality of the data. However, the inclusion of this variable has very little impact on the coefficient on the AFQT score.

${ }^{19}$ See Neal (1998) for a model along these lines. In his model, more able workers choose to work in industries and occupations that offer more specific skills. Neal's model predicts a negative correlation between ability and mobility unconditional on the worker's industry and occupation affiliation. This correlation should disappear after controlling for the worker's occupation and industry affiliation.

${ }_{20}$ The quarterly moving rate is $9.15 \%$ for high school graduates.

${ }^{21}$ The quarterly moving rate is $6.24 \%$ for college graduates.
} 
metric employer learning in favor of the alternative hypothesis of asymmetric learning for college graduates $(p$-value $=.028)$ but not for high school graduates $(p$-value $=.307){ }^{22}$

Of course, there are explanations other than asymmetric information for an adverse selection of movers. For instance, consider an extension of my model that incorporates unemployment, and suppose that low-ability and high-ability workers receive the same utility from unemployment. Such a model predicts that low-ability workers are more likely to become unemployed even if learning is symmetric. However, low-ability workers should not be more likely to move from job to job. Under asymmetric learning, in contrast, job-to-job movers should be of lower ability, too. In panel B of table 3, I therefore distinguish between job-to-job and job-tounemployment transitions and estimate a multinominal logit model, using stayers as the base category. A distinction between job-to-job and job-tounemployment movers turns out to be important. When restricting the impact of the AFQT score to be the same for high school graduates and college graduates (row A, cols. 1 and 2), the AFQT score lowers the probability of becoming unemployed but not the probability of moving from job to job, relative to the probability of staying. This casts further doubt that the lower ability of movers found in panel A, column 1, is driven by informational asymmetries between incumbent and outside firms.

Again, there are interesting differences between education groups, and the hypothesis that there are no differences between high school graduates and college graduates can be rejected at a $5 \%$ level. For high school graduates, the AFQT score decreases the probability of becoming unemployed but not the probability of moving from job to job relative to the probability of staying. For college graduates, in contrast, the AFQT score also reduces the (relative) probability of moving from job to job. This strengthens my previous finding that the hypothesis of symmetric employer learning can be rejected in favor of the alternative hypothesis of asymmetric learning for college graduates but not for high school graduates.

\section{B. Learning by Experience or Tenure?}

I now turn to my second test for asymmetric learning and analyze how in a wage regression the coefficients on the AFQT score and schooling vary with experience and tenure. Table 4 reports the results. All specifications control for occupation and industry affiliation, years of schooling, experience, experience squared, time dummies, and time dummies interacted with years of schooling, in addition to the variables reported

${ }^{22}$ The $p$-values refer to the one-sided hypothesis test $H_{0}: \beta_{\mathrm{AFQT}}=0$ vs. $H_{1}: \beta_{\mathrm{AFQT}}<0$. 


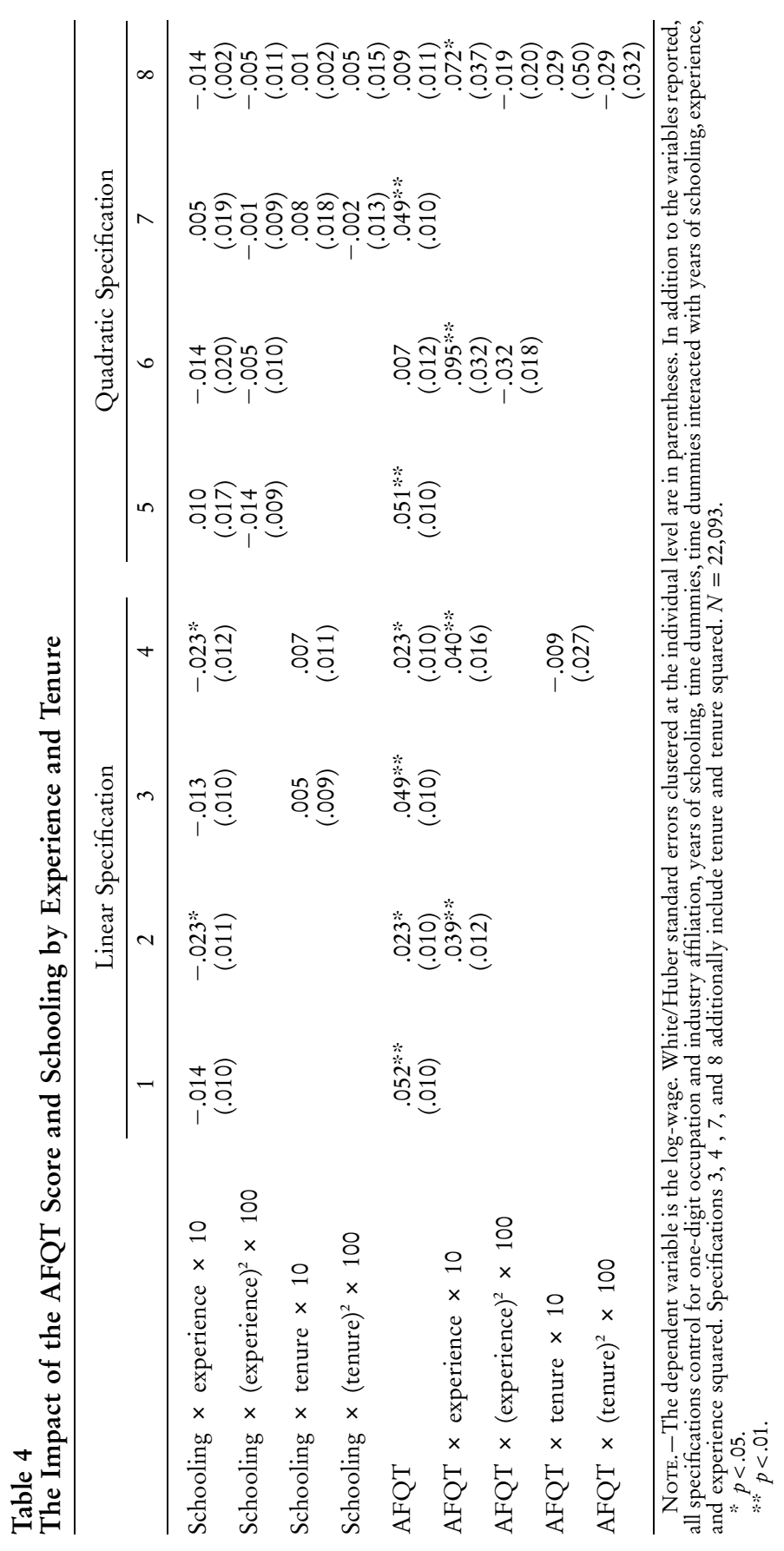


in the table. ${ }^{23}$ The first two columns replicate Altonji and Pierret's analysis using my longer sample that includes data until 2001. ${ }^{24}$ Column 1 includes the AFQT score and years of schooling interacted with experience, while column 2 additionally controls for the AFQT score interacted with experience. I confirm Altonji and Pierret's finding that the impact of the AFQT score on wages increases and the impact of schooling declines with experience.

In order to distinguish between symmetric and asymmetric employer learning, columns 3 and 4 of table 4 additionally include tenure and tenure squared, as well as interactions between tenure, the AFQT score, and schooling. If learning is symmetric, then the coefficients on the tenureschooling and tenure-AFQT score interaction should be zero. Asymmetric employer learning, in contrast, predicts a positive coefficient on the tenure-AFQT score interaction and a negative coefficient on the tenureschooling interaction. Both coefficients are small in magnitude and statistically insignificant. Moreover, their inclusion has little effect on the coefficients on the interactions between experience and the AFQT score and schooling. Hence, for this specification, the hypothesis that employer learning is symmetric cannot be rejected. This is in line with my previous finding that there is little evidence for an adverse selection of movers if I do not distinguish between education groups.

So far, the specification has assumed that the effect of the AFQT score and schooling varies linearly with experience and tenure. However, if firms learn more about inexperienced workers with low levels of tenure, then this restriction may be violated. In columns 5-8 of table 4, I therefore include additional interactions between experience and tenure squared and the AFQT score and schooling. There is indeed some evidence that the impact of the AFQT score increases more at low experience levels than at high experience levels. However, the interactions between the AFQT score and schooling and tenure and tenure squared continue to be small in magnitude and are statistically insignificant. My overall conclusions are thus unchanged.

Finally, following Lange (2007), figure 1 presents results where I have allowed the AFQT score and schooling to have a different impact on logwages at each experience level (panel A) and each tenure level (panel B). The dots (AFQT score) and triangles (schooling) refer to the point estimates, while the solid (AFQT score) and dashed (schooling) lines show the predicted value based on the quadratic specification. While the impact of the AFQT score clearly increases and the impact of schooling clearly

${ }^{23}$ I allow the time effects to vary by education in order to capture the increase in the returns to education during the 1980s.

${ }^{24}$ Altonji and Pierret (2001) use data from the NLSY up to 1992. Unlike my sample, their sample includes blacks and women. 


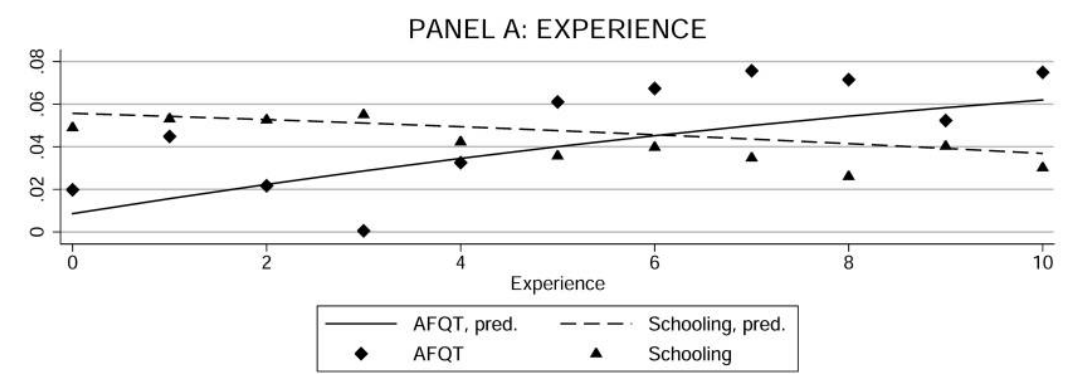

PANEL B: TENURE

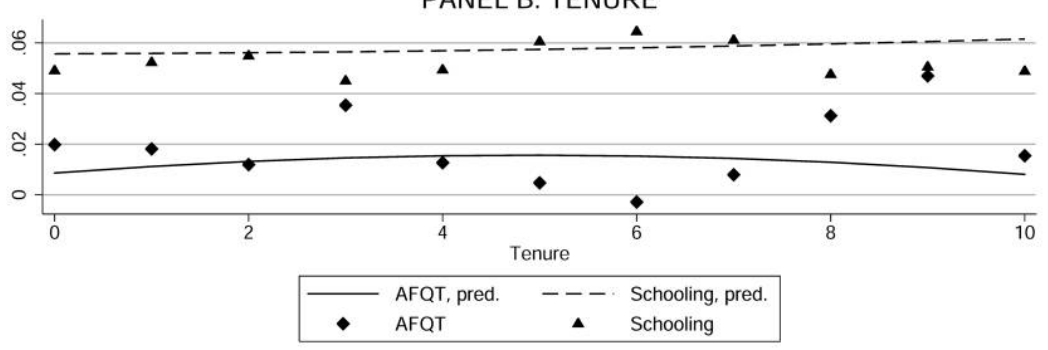

FIG. 1.-The relationship between the AFQT score, schooling, experience, and tenure. The figure shows the impact of the AFQT score and schooling on log-wages at each experience (panel A) and tenure (panel B) level. The dots (AFQT-score) and triangles (schooling) refer to the point estimates, while the solid (AFQT-score) and dashed (schooling) lines show the predicted values based on the quadratic specification (table 5, specification 8).

decreases with experience, there is no clear relationship between the AFQT score (schooling) and tenure. My conclusions thus do not depend on the particular functional form used.

An implicit assumption behind the results in table 4 and figure 1 is that schooling increases the productivity of low-ability workers by as much as it does that of high-ability workers. However, the previous section provided some evidence against this assumption, as the adverse selection of movers is stronger for college graduates than for high school graduates. Next, I therefore present results separately by education. Table 5 reports results for both the linear and quadratic specifications. Specifications 1 and 3 control for time effects, industry and occupation affiliation, experience, experience squared, the AFQT score, and the AFQT score interacted with experience. Specifications 2 and 4 add tenure, tenure squared, and the AFQT score interacted with tenure. For high school graduates, the coefficients on the interaction between the AFQT score and tenure are, contrary to the hypothesis of asymmetric learning, negative (though statistically insignificant), for both the linear and quadratic specification. For this education group, I thus do not reject the hypothesis of symmetric employer learning. For college graduates, the results are somewhat mixed. In the linear specification, 


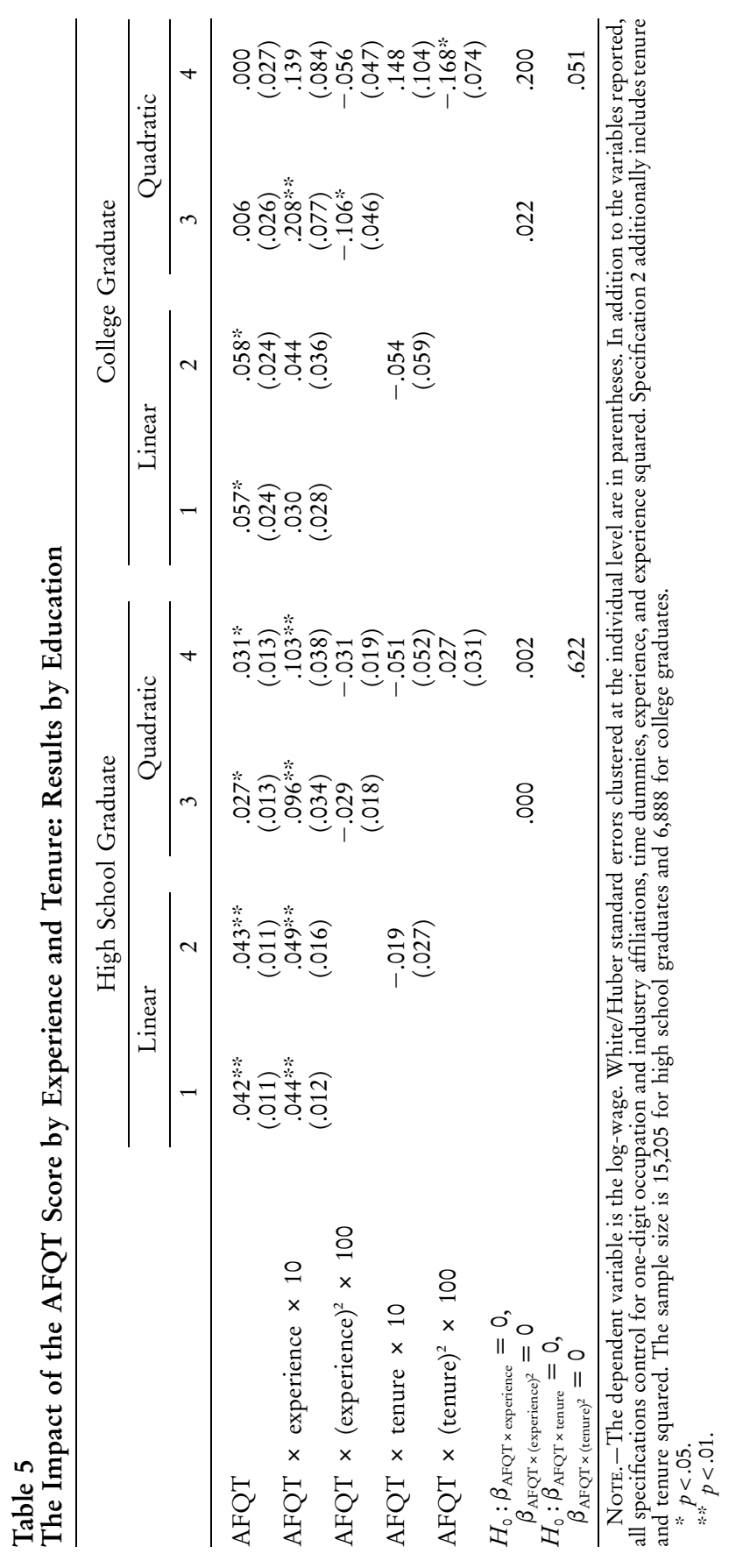


PANEL A: EXPERIENCE

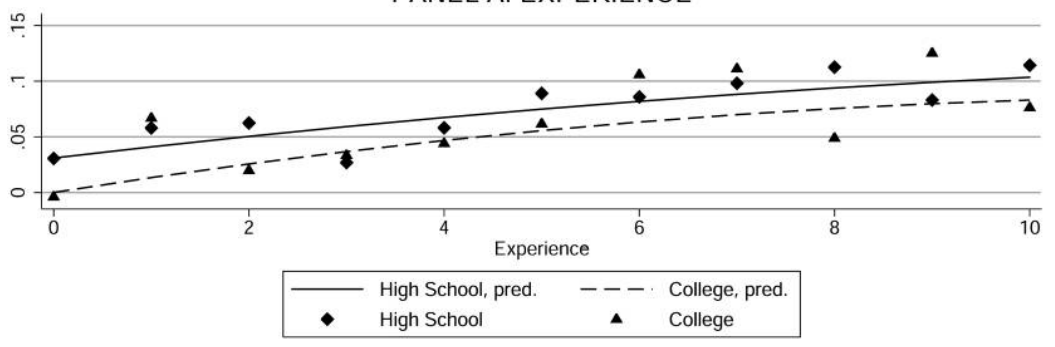

PANEL B: TENURE

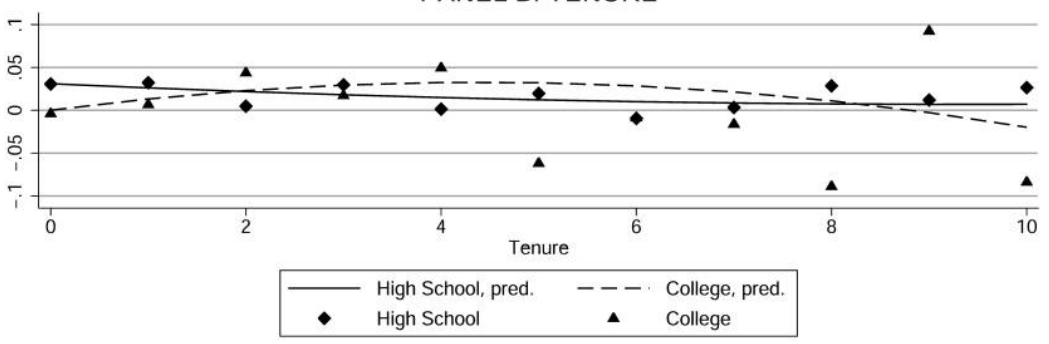

FIG. 2.-The relationship between the AFQT score, experience, and tenure: high school graduates versus college graduates. The figure shows the impact of the AFQT score on logwages at each experience (panel A) and tenure (panel B) level. The dots (high school graduates) and triangles (college graduates) refer to the point estimates, while the solid (high school graduates) and dashed (college graduates) lines plot the predicted value based on the quadratic specification (table 5 , specification 4 ).

the coefficient on the interaction between the AFQT score and tenure is negative and statistically insignificant. The quadratic specification, however, reveals that the impact of the AFQT score is first increasing and then decreasing with tenure. The coefficients are jointly significant at a $5 \%$ level. Evaluated at the mean tenure level of 3.37, the impact of the AFQT score is .0314 as compared to .001 at labor market entry. However, this effect is not statistically different from zero $(p$-value $=.2638) .{ }^{25}$

To further investigate the relationship between AFQT score, experience, and tenure, I next allow the coefficient of the AFQT score to vary with each experience and tenure level. In figure 2, the dots (high school graduates) and triangles (college graduates) refer to the point estimates, while the solid (high school graduates) and dashed (college graduates) plot the predicted value based on the quadratic specification. For both education groups, the impact of the AFQT score becomes larger as experience increases (upper

${ }^{25}$ This is the $p$-value for the two-sided hypothesis test. 
panel). ${ }^{26}$ For high school graduates, the impact of the AFQT score varies little with tenure (lower panel). Hence, for this education group, my conclusions do not depend on the particular functional form between tenure and the AFQT score: I do not reject the hypothesis of symmetric learning for any specification. For college graduates, the picture is less clear cut. The impact of the AFQT score rises with tenure up to the fifth year in the job; after that, the coefficients are-possibly due to the small sample sizeimprecisely estimated. ${ }^{27}$ They jump around a lot, and they sometimes take rather large negative values. It is difficult to draw a definite conclusion from this analysis. The next section summarizes my results and discusses alternative explanations for my findings.

\section{Discussion and Interpretation}

When workers enter the labor market, employers are likely to have only imperfect information about workers' productivities. The question of this article is this: Do both incumbent and recruiting firms symmetrically learn about workers' productivities with time in the labor market, or do incumbent firms have superior information about workers' productivities (asymmetric learning)? I develop a simple learning model that nests both learning hypotheses, and I propose new tests to discriminate between these two hypotheses. Overall, learning appears to be largely symmetric. There is little evidence that workers who leave the firm are negatively selected, in particular if one conditions on industry and occupation affiliation. Moreover, the impact of the AFQT score increases with experience but varies little with tenure. Similarly, the impact of schooling slightly decreases with experience but changes little with tenure.

There are, however, important differences across education groups. My results for high school graduates mirror those for all education groups. In my view, the strongest piece of evidence against asymmetric learning for this education group is that firm-movers are not negatively selected. Adverse selection, however, is a robust feature of all asymmetric learning models with mobility that I know of. ${ }^{28} \mathrm{~A}$ further piece of evidence against asymmetric learning is that the impact of the AFQT score increases with experience but changes little with tenure.

The AFQT score provides a summary measure for basic literacy and numeric skills. It is generally seen as a good proxy of workers' cognitive abilities, but it is probably not as good a proxy for their noncognitive

${ }^{26}$ Note, however, that for college graduates the coefficients on the interactions between the AFQT score and the experience levels are not jointly significant $(p$-value $=.28)$.

${ }^{27}$ I only have 1,604 observations for workers with a college degree and more than 5 years of tenure.

${ }^{28}$ This implication has been especially stressed by Greenwald (1986), Gibbons and Katz (1991), and Acemoglu and Pischke (1998). 
skills, such as reliability, work ethic, and communication skills. It may be argued that, in jobs that are typically performed by high school graduates, noncognitive skills play a more important role than cognitive skills. For high school graduates, the AFQT score may therefore not be the right ability measure to discriminate between asymmetric and symmetric learning. My results do not rule out the possibility that incumbent firms have superior information about workers' noncognitive skills. Unfortunately, my data do not allow me to detect this. However, I would like to stress that the AFQT score is strongly correlated not only with wages of college graduates but also with wages of high school graduates. Hence, the reason why I do not reject the hypothesis of symmetric learning for high school graduates is not that the AFQT score has little impact on wages.

For college graduates, in contrast, my results are somewhat mixed. On the one hand, low-ability workers are more likely to switch firms than are high-ability workers. This adverse selection is not fully explained by the sorting of high-ability workers into occupations and industries with low turnover rates. Moreover, the adverse selection of movers is not only driven by low-ability workers being more likely to become unemployed but also by low-ability workers being more likely to move from job to job. On the other hand, there is no clear-cut evidence that the impact of the AFQT score rises with tenure. This appears to be the case for low levels of tenure ( $\leq 4$ years). For higher levels of tenure, however, my estimates are very imprecise, and-contrary to the hypothesis of asymmetric learning-they sometimes take large negative values.

Moreover, there may be explanations other than asymmetric learning for my findings for college graduates. One possible candidate is a human capital model in which more able workers accumulate more firm-specific human capital. Like asymmetric learning, such a model predicts that highability workers are less likely to switch firms. It also implies that the impact of the AFQT score rises with tenure. Several studies find that education (e.g., Mincer 1988; Lynch 1992), as well as high aptitude and achievement measures (Altonji and Spletzer 1991), increase the probability of receiving training, and thus they illustrate that a complementarity between ability and firm-specific human capital is of potential concern.

Another possible explanation for my findings for college graduates is an assignment model combined with symmetric employer learning. Consider a two-period symmetric learning model (in the spirit of Gibbons and Katz 1992) with two types of firms, $A$ and $B$. Productivity in type $B$ firms is more sensitive to ability than productivity in type $A$ firms; in particular, assume that the productivity of low-ability and high-ability workers in firms of type $A$ and $B$ can be ranked as follows: $y_{H, B}>$ $y_{H, A}>y_{L, B}>y_{L, A}$. This ranking implies that, efficiently, high-ability workers are assigned to firm $B$ and low-ability workers are assigned to firm $A$. Unlike as in my model, there are no nonpecuniary job characteristics and 
wages are equal to expected productivity. Each period, firms receive a signal about a worker's ability. As in my set-up, the signal can take two values, good $(G)$ and bad $(B)$. While this model does not necessarily produce the same implications as my asymmetric learning model, there is a parameterization for which this is the case. Suppose that, in the first period, all workers are assigned to firms of type $B$, regardless of whether they received a good or a bad signal. In the second period, all workers who generated two bad signals move down to type $A$ firms. The probability of receiving two bad signals is higher for low-ability workers than for high-ability workers $\left(q^{2}\right.$ vs. $\left.(1-q)^{2}\right)$; hence, movers are negatively selected in terms of ability. ${ }^{29}$ Moreover, note that all movers work in type $A$ firms, and earn a wage equal to the expected productivity of workers with two bad signals in type $A$ firms. Wages of movers thus do not depend on ability. Wages of stayers, in contrast, vary with ability, ${ }^{30}$ as stayers consist of workers who received either two good or one good and one bad signal. Hence, for this parameterization, the model also predicts that the impact of ability measures rise with tenure. I am not able to rule out this alternative explanation.

To conclude, learning about cognitive ability appears to be largely symmetric. However, for college graduates, the empirical evidence is potentially consistent with a model of asymmetric employer learning. There may, however, be alternative explanations for my findings.

\section{Appendix A}

\section{Theory Appendix}

\section{Uniqueness of Equilibrium}

To simplify the notation, I drop the superscripts $k$ (college) and $s$ (signal). The argument is the same for workers with a good or a bad signal

${ }^{29}$ If, in contrast, all workers are initially assigned to firm A and workers receiving two good signals in a row move to firm B, the model predicts that highability workers are more likely to switch firms.

${ }^{30}$ Wages of high-ability workers who stay with the firm equal

$$
\frac{q^{2} w_{B}^{G G}+q(1-q) w_{B}^{G B}}{q^{2}+q(1-q)},
$$

while wages of low-ability workers who stay with the firm equal

$$
\frac{q(1-q) w_{B}^{B G}+(1-q)^{2} w_{B}^{G G}}{q(1-q)+(1-q)^{2}},
$$

where $w_{f}^{s s}$ denotes the wage of workers with signal sequence ss in firm $f ; s=$ $G, B ; f=A, B$. 
and for workers who did or did not attend college. From (3), the firstorder condition for incumbent firms is

$$
w_{i}=y_{i}-\frac{1-G\left(v-w_{i}\right)}{g\left(v-w_{i}\right)}, \quad i=L, H .
$$

From (4), wage offers of outside firms are implicitly defined as

$$
v=\frac{p G\left(v-w_{L}\right) y_{L}+(1-p) G\left(v-w_{H}\right) y_{H}}{p G\left(v-w_{L}\right)+(1-p) G\left(v-w_{H}\right)} .
$$

Log-concavity of $G$ ensures that $\left[1-G\left(v-w_{i}\right)\right] / g(v-w)$ is nondecreasing in $w$. Hence, the incumbent's objective function is quasi-concave and the second-order conditions for a maximum are satisfied.

I next show that the equilibrium is unique. Totally differentiating (A1) with respect to $v$ yields

$$
\frac{d w_{i}}{d v}=\frac{\left[g_{i}^{2}+\left(1-G_{i}\right) g_{i}^{\prime}\right] / g_{i}^{2}}{1+\left[g_{i}^{2}+\left(1-G_{i}\right) g_{i}^{\prime}\right] / g_{i}^{2}},
$$

where $G_{i}=G\left(v-w_{i}\right)$ and $g_{i}=g\left(v-w_{i}\right)$. By log-concavity of $G$, $\left[g_{i}^{2}+\left(1-G_{i}\right) g_{i}^{\prime}\right] / g_{i}^{2}>0$. Hence, an increase in $v$ by one unit increases $w_{i}$, but it does so by less than one unit. If an increase in $w_{L}$ and $w_{H}$ by one unit also increases $v$ by less than one unit, then the equilibrium is unique. Totally differentiating (A2) and $w_{H}$ yields

$$
\begin{aligned}
& d v= \\
& \frac{\left[p(1-p)\left(y_{H}-y_{L}\right)\left(g_{L} G_{H} d w_{L}-G_{L} g_{H} d w_{H}\right)\right] /\left[p G_{L}+(1-p) G_{H}\right]^{2}}{1+\left\{\left[p(1-p)\left(y_{H}-y_{L}\right)\left(g_{L} G_{H} d w_{L}-G_{L} g_{H} d w_{H}\right)\right] /\left[p G_{L}+(1-p) G_{H}\right]^{2}\right\}} .
\end{aligned}
$$

Log-concavity of $G$ ensures that an increase in $w_{L}$ and $w_{H}$ by one unit leads to an increase of $v$ by less than a unit.

\section{Wage Determination in the First Period}

In the first period, firms observe a worker's education but not his or her ability. First-period wages therefore depend on education but not on ability. In the first period, firms bid up wages until they earn zero expected profits. Note that, in the second period, workers are paid a wage below their productivity, due to nonpecuniary job characteristics as well as (possibly) information asymmetries. This implies that first-period wages exceed expected productivity.

Let $\Pi^{k}, k=C, N$, denote the firm's expected profit in the second period. First-period wages then satisfy

$$
W^{k}=p^{k} y_{L}^{k}+\left(1-p^{k}\right) y_{H}^{k}+\Pi^{k} .
$$




\section{The Impact of Ability on the Probability of Moving}

I first show that if $q=1$, then wage offers of incumbent firms are equal to the worker's productivity minus a (positive) constant. For simplicity, I drop the superscript $k$. With symmetric learning, outside firms offer $v_{i}=y_{i}$. Totally differentiating the incumbent firm's first-order condition (A1) with respect to $y_{i}$ and using $v_{i}=y_{i}$ yields

$$
\frac{d w_{i}}{d y_{i}}=1
$$

Hence, an increase in productivity by one unit raises wage offers of incumbent firms by one unit; wage offers of incumbent firms are therefore equal to the worker's productivity minus a constant. This implies that highability workers are as likely to switch firms as are low-ability workers.

Next, I show that, if $q<1$, low-ability workers are more likely to leave the firm than are high-ability workers, unconditional on the signal observed by employers. The probability that a low-ability worker leave the firm equals

$$
q G\left(v^{B}-w_{L}^{B}\right)+(1-q) G\left(v^{G}-w_{L}^{G}\right),
$$

while the probability that a high-ability worker leaves the firm equals

$$
q G\left(v^{G}-w_{H}^{G}\right)+(1-q) G\left(v^{B}-w_{H}^{B}\right) .
$$

The following two conditions are sufficient for the quit rate of low-ability workers to be higher than that of high-ability workers:

$$
\begin{aligned}
& G\left(v^{B}-w_{L}^{B}\right)-G\left(v^{G}-w_{H}^{G}\right)>0 \Leftrightarrow w_{H}^{G}-w_{L}^{B}>v^{G}-v^{B}, \\
& G\left(v^{G}-w_{L}^{G}\right)-G\left(v^{B}-w_{H}^{B}\right)>0 \Leftrightarrow v^{G}-v^{B}>w_{L}^{G}-w_{H}^{B} .
\end{aligned}
$$

Consider inequality (A3). Suppose $q=0.5$. In this case, $v^{B}=v^{G}=v$; $w_{H}^{G}=w_{H}^{B}=w_{H}$; and $w_{L}^{G}=w_{L}^{B}=w_{L}$. Clearly, the inequality holds. Next, suppose that $q=1$. In this case, $w_{H}^{G}-w_{L}^{B}=v^{G}-v^{B}=a_{H}-a_{L}$. Hence, if one can show that, for $q \leq 0.5<1, d\left[\left(w_{H}^{G}-w_{L}^{B}\right)-\left(v^{G}-v^{B}\right)\right] / d q<0$, then inequality (A3) holds. A sufficient condition for this to be the case is $d\left(w_{H}^{G}-v^{G}\right) / d q<0$ and $d\left(v^{B}-w_{L}^{B}\right) / d q<0$. Totally differentiating the firstorder condition (A1) yields

$$
\frac{d w_{i}^{s}}{d q}=\frac{\left[g_{i}^{s 2}+\left(1-G_{i}^{s}\right) g_{i}^{s^{\prime}}\right] / g_{i}^{s 2}}{1+\left\{\left[g_{i}^{s 2}+\left(1-G_{i}^{s}\right) g_{i}^{s^{\prime}}\right] / g_{i}^{s 2}\right\}} \frac{d v^{s}}{d q} .
$$


Hence,

$$
\begin{aligned}
& \frac{d w_{H}^{G}}{d q}-\frac{d v^{G}}{d q}=-\frac{1}{1+\left\{\left[g_{H}^{G 2}+\left(1-G_{H}^{G}\right) g_{H}^{G^{\prime}}\right] / g_{H}^{G 2}\right\}} \frac{d v^{G}}{d q} \\
& \frac{d v^{B}}{d q}-\frac{d w_{L}^{B}}{d q}=\frac{1}{1+\left\{\left[g_{L}^{B 2}+\left(1-G_{L}^{B}\right) g_{L}^{B^{\prime}}\right] / g_{L}^{B 2}\right\}} \frac{d v^{B}}{d q} .
\end{aligned}
$$

By log-concavity of $G, d w_{H}^{G} / d q-d v^{G} / d q<0$ if $d v^{G} / d q>0$ and $d v^{B} / d q-d w_{L}^{B} / d q<0$ if $d v^{B} / d q<0$. Formally,

$$
\begin{aligned}
& \frac{d v^{G}}{d q}= \\
& \frac{\left[p(1-p) G_{L}^{G} G_{H}^{H}\left(y_{H}-y_{L}\right)\right] /\left[p(1-q) G_{L}^{G}+(1-p) q G_{H}^{G}\right]^{2}}{\left.1+\left\{\left[\left(y_{H}-y_{L}\right) p(1-p) q(1-q)\left(G_{H}^{G} g_{L}^{G} C_{L}^{G}-G_{L}^{G} g_{H}^{G} C_{H}^{G}\right)\right] /\left[p(1-q) G_{L}^{G}+(1-p) q G_{H}^{G}\right)\right]^{2}\right\}^{-}}>0, \\
& \frac{d v^{B}}{d q}= \\
& -\frac{\left[p(1-p) G_{L}^{B} G_{H}^{B}\left(y_{H}-y_{L}\right)\right] /\left[p q G_{L}^{B}+(1-p)(1-q) G_{H}^{B}\right]^{2}}{1+\left\{\left[\left(y_{H}-y_{L}\right) p(1-p) q(1-q)\left(G_{H}^{B} g_{L}^{B} c_{L}^{B}-G_{L}^{B} g_{H}^{B} C_{H}^{B}\right)\right] /\left[p q G_{L}^{B}+(1-p)(1-q) G_{H}^{B}\right]^{2}\right\}^{2}}<0,
\end{aligned}
$$

where $c_{i}^{s}=1 /\left\{1+\left[g_{i}^{s 2}+\left(1-G_{i}^{s}\right) g_{i}^{s^{\prime}}\right] / g_{i}^{s 2}\right\}$. These results are intuitive: if the precision of the signal increases, then the probability that a worker is of high (low) ability increases if a good (bad) signal is observed.

Next, consider inequality (A4). Clearly, for $q=0.5$, the condition is satisfied, as the left-hand side is zero and the right-hand side is negative. Hence, if I can show that $d\left[\left(v^{G}-v^{B}\right)-\left(w_{L}^{G}-w_{H}^{B}\right)\right] / d q>0$, inequality (A4) holds. A sufficient condition for this to be the case is $d\left(v^{G}-w_{L}^{G}\right) / d q>0$ and $d\left(w_{H}^{B}-v^{B}\right) / d q>0$. This is true if $d v^{G} / d q>0$ and $d v^{B} / d q<0$, and this was shown above. Hence, low-ability workers are more likely to leave the firm unconditional on the signal observed (integrating over the signal distribution).

\section{The Impact of Ability on Wage Offers of Incumbent and Outside Firms}

This section shows that, if $q<1$, wage offers of incumbent firms vary more with ability than wage offers of outside firms, unconditional on the signal observed by employers. The difference between wage offers of incumbent firms to high-ability and low-ability workers equals

$$
\left.E[w \mid H]-E[w \mid L]=\left[q w_{H}^{G}+(1-q) w_{H}^{B}\right)\right]-\left[q w_{L}^{B}+(1-q) w_{L}^{G}\right],
$$


while the difference between wage offers of outside firms to high-ability and low-ability workers equals

$$
E[v \mid H]-E[v \mid L]=\left[q v^{G}+(1-q) v^{B}\right]-\left[q v^{B}+(1-q) v^{G}\right] .
$$

I have to show that $E[w \mid H]-E[w \mid L]>E[v \mid H]-E[w \mid L]$. The following two conditions are sufficient for this to hold:

$$
\begin{aligned}
& w_{H}^{G}-w_{L}^{B}+v^{B}-v^{G}>0 \\
& v^{G}-w_{L}^{G}+w_{H}^{B}-v^{B}>0 .
\end{aligned}
$$

These are conditions (A3) and (A4), which were proved in Appendix A, Section 3.

\section{The Impact of Schooling on Wage Offers of Incumbent and Outside Firms}

This section shows that, for $q<1$, wage offers of outside firms vary more with education than wage offers of incumbent firms, conditional on ability. I present the analysis for low-ability workers, but the same argument applies to high-ability workers. The average difference between wage offers of incumbent firms to high school graduates and college graduates equals

$$
E[w \mid C, L]-E[w \mid N, L]=q\left(w_{L}^{C, B}-w_{L}^{N, B}\right)+(1-q)\left(w_{L}^{C, G}-w_{L}^{N, G}\right),
$$

while the average difference between wage offers of outside firms to high school graduates and college graduates equals

$$
E[v \mid C, L]-E[v \mid N, L]=q\left(v^{C, B}-v^{N, B}\right)+(1-q)\left(v^{C, G}-v^{N, G}\right) .
$$

I have to show that $E[w \mid C, L]-E[w \mid N, L]<E[v \mid C, L]-E[v \mid N, L]$. A sufficient condition for this inequality to hold is, for good as well as bad signals, $w_{L}^{C, s}-w_{L}^{N, s}<v^{C, s}-v^{N, s}$. Note that for $s=0$ and $p^{N}=p^{C}$, $w_{i}^{C, s}=w_{i}^{N, s}$ and $v^{C, s}=v^{N, s}$. Hence, if an increase in $s$ and a decline in $p^{C}$ raises wage offers of outside firms by at least as much as wage offers of incumbent firms, then $w_{i}^{C, s}-w_{i}^{N, s}<v^{C, s}-v^{N, s}$. Since schooling has the same impact on the productivity of low-ability and high-ability workers,

$$
\frac{d v^{C, s}}{d s}=\frac{d w_{i}^{C, s}}{d s}=1
$$

Totally differentiating (A1) with respect to $\left(1-p^{C}\right)$ yields

$$
\frac{d w_{i}^{C, s}}{d\left(1-p^{C}\right)}=\frac{\left[g_{i}^{C, s 2}+\left(1-G_{i}^{C, s}\right) g_{i}^{C, s^{\prime}}\right] / g_{i}^{C, s 2}}{1+\left\{\left[g_{i}^{C, s 2}+\left(1-G_{i}^{C, s}\right) g_{i}^{C, s^{\prime}}\right] / g_{i}^{C, s 2}\right\}} \frac{d v^{C, s}}{d\left(1-p^{C}\right)} .
$$

By $\log$-concavity of $G, d w_{i}^{C, s} / d\left(1-p^{C}\right)<d v^{C, s} / d\left(1-p^{C}\right)$. Hence, school- 
ing has a greater impact on wage offers of outside firms than on those of incumbent firms for both low-ability and high-ability workers.

\section{Complementarity between Ability and Schooling}

I first show that if ability and education are complements, then the difference between the impact of ability on wage offers of incumbent firms and outside firms is stronger for college graduates than for high school graduates. Consequently, the adverse selection is stronger for college graduates than for high school graduates. For simplicity, I model the complementarity between ability and education in a multiplicative manner, that is,

$$
y_{L}^{C}=s \times a_{L}, \quad y_{H}^{C}=s \times a_{H}, \quad y_{L}^{N}=a_{L}, \quad \text { and } y_{H}^{N}=a_{H} .
$$

I have to show that

$$
\begin{aligned}
& \frac{(E[w \mid C, H]-E[w \mid C, L])-(E[v \mid C, H]-E[v \mid C, L])}{\text { college graduates }} . \\
\geq & \frac{(E[w \mid N, H]-E[w \mid N, L])-(E[v \mid N, H]-E[v \mid N, L])}{\text { high school graduates }}
\end{aligned}
$$

Rewriting,

$$
\begin{gathered}
{\left[\left(q w_{H}^{C, G}+(1-q) w_{H}^{C, B}\right)-\left(q w_{L}^{C, B}+(1-q) w_{L}^{C, G}\right]\right.} \\
-\left[\left(q v^{C, G}+(1-q) v^{C, B}\right]-\left[q v^{C, B}+(1-q) v^{C, G}\right] \geq\right. \\
{\left[\left(q w_{H}^{N, G}+(1-q) w_{H}^{N, B}\right)-\left(q w_{L}^{N, B}+(1-q) w_{L}^{N, G}\right)\right]} \\
-\left[\left(q v^{N, G}+(1-q) v^{N, B}\right]-\left[q v^{N, B}+(1-q) v^{N, G}\right] .\right.
\end{gathered}
$$

Rearranging,

$$
\begin{aligned}
& q\left(w_{H}^{C, G}-v^{C, G}\right)+(1-q)\left(w_{H}^{C, B}-v^{C, B}\right) \\
& \quad+q\left(v^{C, B}-w_{L}^{C, B}\right)+(1-q)\left(v^{C, G}-w_{L}^{C, G}\right) \geq \\
& q\left(w_{H}^{N, G}-v^{N, G}\right)+(1-q)\left(w_{H}^{N, B}-v^{N, B}\right) \\
& \quad+q\left(v^{N, B}-w_{L}^{N, B}\right)+(1-q)\left(v^{N, G}-w_{L}^{N, G}\right) .
\end{aligned}
$$


Suppose that $p^{N}=p^{C}=p \cdot{ }^{31}$ If $s=0$, then $v^{C, s}=v^{N, s}$ and $w_{i}^{C, s}=w_{i}^{N, s}$. Hence, a sufficient condition for the inequality given above to hold is that an increase in $s$ raises incumbent wage offers of high-ability workers by more and wage offers of low-ability workers by less than outside wage offers regardless of which type of signal is observed. Totally differentiating (A1) yields

$$
\begin{aligned}
\frac{d w_{L}^{s}}{d s} & =\frac{a_{L}+\left(\left\{\left[g_{L}^{s 2}+\left(1-G_{L}^{s}\right) g_{L}^{s^{\prime}}\right] / g_{L}^{s 2}\right\}\left\{d v^{s} / d s\right\}\right)}{1+\left\{\left[g_{L}^{s 2}+\left(1-G_{L}^{s}\right) g_{L}^{s^{\prime}}\right] / g_{L}^{s 2}\right\}}, \\
\frac{d w_{H}^{s}}{d s} & =\frac{a_{H}+\left(\left\{\left[g_{H}^{s 2}+\left(1-G_{H}^{s}\right) g_{H}^{s^{\prime}}\right] / g_{H}^{s 2}\right\}\left\{d v^{s} / d s\right\}\right)}{1+\left\{\left[g_{H}^{s 2}+\left(1-G_{H}^{s}\right) g_{H}^{s^{\prime}}\right] / g_{H}^{s 2}\right\}} .
\end{aligned}
$$

Hence, $d w_{L}^{C, s} / d s<d v^{C, s} / d s<d w_{H}^{C, s} / d s$ if $a_{L}<d v^{C, s} / d s<a_{H}$. Totally differentiating (A2) with respect to $s$ yields the equation that is displayed as figure A1. It may be verified that $a_{L}<d v^{C, B} / d s<a_{H}$. A similar formula can be derived for $v^{C, G}$.

Next, I argue that, for high-ability workers, education may have a stronger or a weaker impact on wage offers of incumbent firms than those of outside firms. From Appendix A, Section 5, I can be sure that wage offers of outside firms are more sensitive to education than wage offers of incumbent firms if an increase in $s$ and a decrease in $p^{C}$ increases wage offers of outside firms by more than wage offers of incumbent firms. While a decrease $p^{c}$ continues to have a stronger impact on outside wage offers (i.e., $\left.d w_{i}^{C, s} / d\left(1-p^{C}\right)<d v^{C, s} / d\left(1-p^{C}\right)\right)$, s has, for high-ability workers, a stronger impact on incumbent wage offers (i.e., $d w_{H}^{C, s} / d s>d v^{C, s} / d s$ ). For lowability workers, in contrast, both effects work in the same direction (i.e., $\left.d w_{L}^{C, s} / d s<d v^{C, s} / d s\right)$.

\section{Appendix B}

\section{Data Appendix}

\section{Definition of Labor Market Entry}

My definition for a transition from school to work closely follows Farber and Gibbons's (1996) definition. The difference between their def-

${ }^{31}$ With asymmetric learning, the adverse selection, as well as the difference between the impact of ability in incumbent and outside wage offers, may vary with education even if ability and education are not complements. This is because the ability distribution may be more or less dispersed for college graduates than for high school graduates. The informational asymmetry tends to be the smaller the closer the fraction of low-ability workers is to 0 or 1 . However, results from numerical simulations show that it is not necessarily true that the adverse selection and the difference between the impact of ability on wage offers of incumbent and outside firms is strongest when $p=.5$. 


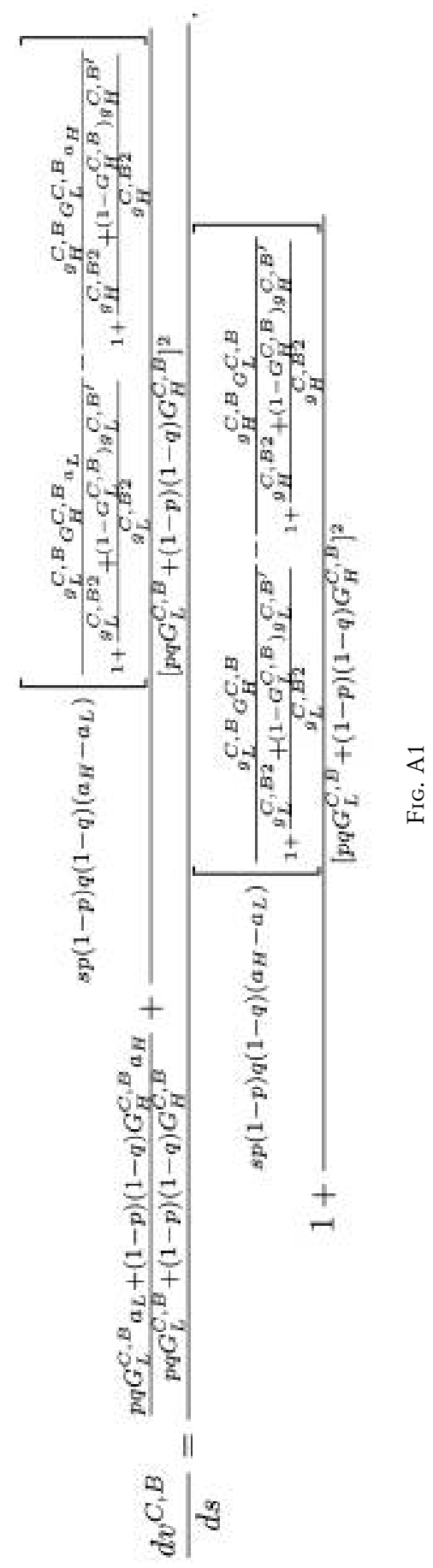


inition and mine is that my definition is based on calendar years, theirs on interview years. I prefer calendar years because the time between two interviews varies from 9 to 40 or more months. According to this definition, labor market entry takes place when the worker was classified as nonworking for at least 1 year, followed by at least 2 consecutive years classified as working. A worker is classified as working when he has worked full time at least 26 weeks in a calendar year. It sometimes happens that the worker was employed for the same employer before he made the transition from school to work. I include these spells in my analysis.

\section{Creation of Spell Data from Quarterly Data}

For my second set of tests, I transform the quarterly data set into a spell data set. Here, I first drop all nonemployment spells. I then keep one valid observation per job and interview year. I drop observations for the sixth job and higher in an interview year since the NLSY collects information on only a maximum of five jobs between two interviews. It sometimes happens that the worker's secondary job becomes his main job. In this case, the job number in the quarterly data changes although the worker does not switch employers. If the (previously) secondary job started after and ended before the main job, I ignore it. It can also happen that the "new" job in the quarterly data started before the previous job started or that the previous job ended after the "new" job ended. When jobs overlap in this way, I only consider the job at which the worker worked most. After eliminating dual jobs in this way, I compute the tenure and experience variables. I then drop part-time jobs ( $<30$ hours), jobs without pay, jobs of the self-employed, and jobs in the agricultural sector. I also drop observations where the wage is smaller than $\$ 1$ or greater than $\$ 500$.

\section{Variable Definitions}

Probability of moving: For each quarter, I observe the worker's employment status and job number (main job) at the beginning of the quarter, as well as the week he started and stopped working for the employer. I use this information to compute quarterly quit rates. It is possible that a worker temporarily leaves his job (e.g., because he is on recall) and returns to the job later. I consider these workers as stayers. It sometimes happens that the worker's secondary job becomes his main job. In this case, the job number in the quarterly data changes. I consider these workers as movers.

Probability of a job-to-job and job-to-unemployment transition: I consider a firm switch as a job-to-unemployment transition if the respondent reported that he was actively searching for a job between the two employment spells. My results are similar if I classify a transition as 
a job-to-unemployment transition if the worker started the new job 4 weeks or later after his old job ended, independently of whether the worker was actively looking for a job.

Education and highest grade: The definition for education is based on the variable "highest grade completed." High school graduates are workers who, during their last interview year, had less than 16 years of education. High school graduates include high school dropouts as well as college dropouts. College graduates are workers who, during their last interview year, had at least 16 years of education. For workers with less than 8 years of schooling, I assign a highest grade of 8 . There are some inconsistencies in the variable "highest grade completed." For instance, it may happen that in 3 consecutive years the education variable first increases and then decreases by 1 year. In these cases, I assign the lower value in the first and third year.

Experience and tenure, spell data: Actual experience is measured as weeks (divided by 53) spent in employment after the transition from school to work. It is based on the start and stop date of each job. Tenure is measured as weeks (divided by 53) spent in employment with the same employer. As actual experience, the tenure variable is based on the start and stop date of each job. (Hence, time on recall is counted as experience and tenure.)

Experience and tenure, quarterly data: For the quarterly data, I compute experience as the sum of the number of weeks worked in a quarter (divided by 53). Tenure is computed as the sum of the number of weeks worked for the same employer in a quarter (divided by 53 ).

Wage rate: The wage rate is the hourly wage rate, which was computed by the Bureau of Labor Statistics. I assume that wages refer to tenure and experience at the end of the employment spell. Results change very little if we assume that wages refer to tenure and experience at the beginning of each employment spell. I deflate wages by the Consumer Price Index with 1982 as the base year.

Occupation and industry affiliation: I distinguish seven occupations: professional, technical, and kindred; managers; sales workers, clerical and kindred; craftsmen, foremen, and kindred; operatives and kindred; laborers; and service workers. I distinguish 12 industries: mining; construction; manufacturing; transportation, communication, and public utilities; wholesale trade; retail trade; finance, insurance, and real estate; business and repair services; personnel services; entertainment and recreation services; professional and related services; and public administration.

\section{References}

Acemoglu, Daron, and Jörn-Steffen Pischke. 1998. Why do firms train? Theory and evidence. Quarterly Journal of Economics 113, no. 1:79-119. 
Altonji, Joseph G., and Charles R. Pierret. 2001. Employer learning and statistical discrimination. Quarterly Journal of Economics 116, no. 1: 313-50.

Altonji, Joseph G., and James R. Spletzer. 1991. Worker characteristics, job characteristics, and the receipt of on-the-job training. Industrial and Labor Relations Review 45, no. 1:58-71.

Bauer, Thomas K., and John P. Haisken-DeNew. 2001. Employer learning and the returns to schooling. Labour Economics 8, no. 2:161-80.

Bernhardt, Dan. 1995. Strategic promotion and compensation. Review of Economic Studies 62, no. 2:315-39.

Bernhardt, Dan, and David Scoones. 1993. Promotion, turnover, and preemptive wage offers. American Economic Review 83, no. 4:771-91.

Cawley, John, James Heckman, and Edward Vytlacil. 2001. Three observations on wages and measured cognitive ability. Labour Economics 8, no. 4:419-42.

DeVaro, Jed, and Michael Waldman. 2004. The signaling role of promotions: Further theory and empirical evidence. Unpublished manuscript, School of Industrial and Labor Relations, Cornell University.

Doiron, Denise J. 1995. Lay-offs as signals: The Canadian evidence. Canadian Journal of Economics 28, no. 4:899-913.

Farber, Henry S., and Robert Gibbons. 1996. Learning and wage dynamics. Quarterly Journal of Economics 111, no. 4:1007-47.

Freeman, Smith. 1977. Wage trends as performance displays productive potential: A model and application to academic early retirement. Bell Journal of Economics 8, no. 2:419-43.

Galindo-Rueda, Fernando. 2003. Employer learning and schooling-related statistical discrimination in Britain. Discussion Paper no. 778, Institute for the Study of Labor (IZA), Bonn.

Gibbons, Robert, and Lawrence F. Katz. 1991. Layoffs and lemons. Journal of Labor Economics 9, no. 4:351-80.

1992. Does unmeasured ability explain inter-industry wage differentials? Review of Economic Studies 59, no. 3:515-35.

Golan, Limor. 2002. Intra-firm bargaining and wage dynamics: A model of asymmetric learning. Unpublished manuscript, Tepper School of Business, Carnegie Mellon University.

- 2005. Counteroffers and efficiency in competitive labor markets with asymmetric information. Journal of Labor Economics 23, no. 2: 373-93.

Greenwald, Bruce C. 1986. Adverse selection in the labor market. Review of Economic Studies 53, no. 3:325-47.

Grund, Christian. 1999. Stigma effects of layoffs? Evidence from German micro-data. Economics Letters 64, no. 2:241-47.

Harris, Milton, and Bengt Holmstrom. 1982. A theory of wage dynamics. Review of Economic Studies 49, no. 3:315-33. 
Heckman, James, and Edward Vytlacil. 2001. Identifying the role of cognitive ability in explaining the level of change in the return to schooling. Review of Economics and Statistics 83, no. 1:1-12.

$\mathrm{Hu}$, Luojia, and Christopher R. Taber. 2005. Layoffs, lemons, race, and gender. Working Paper no. 11481, National Bureau of Economic Research, Cambridge, MA.

Krashinsky, Harry. 2002. Evidence on adverse selection and establishment size in the labor market. Industrial and Labor Relations Review 56, no. 1:84-96.

Laing, Derek. 1994. Involuntary layoffs in a model with asymmetric information concerning worker ability. Review of Economic Studies 61, no. 2:375-92.

Lange, Fabian. 2007. The speed of employer learning. Journal of Labor Economics 25, no. 1:1-35.

Lynch, Lisa M. 1992. Private-sector training and earnings of young workers. American Economic Review 82, no. 1:299-312.

Meghir, Costas, and Marten Palme. 2005. Educational reform, ability, and parental background. American Economic Review 95, no. 1:414-24.

Mincer, Jacob. 1988. Job training, wage growth, and labor turnover. Working Paper no. 2690, National Bureau of Economic Research, Cambridge, MA.

Neal, Derek. 1998. The link between ability and specialization: An explanation for the observed correlations between wages and mobility rates. Journal of Human Resources 33, no. 1:173-200.

Pinkston, Joshua C. 2005. A model of asymmetric employer learning with testable implications. Working Paper no. 390, Bureau of Labor Statistics, Washington, DC.

Waldmann, Michael. 1984. Job assignment, signalling, and efficiency. Rand Journal of Economics 15, no. 2:255-67.

- 1990. Up-or-out-contracts: A signalling perspective. Journal of Labor Economics 8, no. 2:230-50.

- 1996. Asymmetric learning and the wage/productivity relationship. Journal of Economic Behavior and Organization 31, no. 3:419-29. 